\title{
Mitolojiden Genel Kamu Hukukuna "Canavar Yaratık" Olgusu: Leviathan, Behemot, Rahav, Yılan ve Ejderha
}

\author{
Adil ŞAHIN ${ }^{1}$ \\ Atila DOĞAN ${ }^{2}$
}

ÖZ: "Canavar ve bu canavarın öldürülmesi" mitolojik öykülerde yayginlıla kullanilır. Sümer ve Babil mitolojisinde de canavar öyküleri vardır. Sözü edilen bu öykülerde canavarın bazen adı da bellidir. Leviathan, Babil mitolojisinde geçen bir canavardır. Kitab-l Mukaddes de, bir canavar olarak Leviathan'dan bahseder. Thomas Hobbes da, iki eserine başllk olarak iki canavarın adin vermiştir. Anılan bu iki canavar da, Kitab-ı Mukaddes'te geçer. Bu makalede, canavarı, mitolojideki, Kitab-ı Mukaddes'teki ve genel kamu hukukundaki (Thomas Hobbes) anlamı üzerinde durulacaktır.

Anahtar Kelimeler: Genel Kamu Hukuku, Thomas Hobbes, Leviathan, Behemot, Rahav.

\section{From Mythology to General Public Law the "Monster Creature" Event: Leviathan, Behemoth, Rahab, Snake and Dragon}

ABSTRACT: "The monster and the killing of this monster" is used widely in mythological stories. There are also monster stories in Sumerian and Babylonian mythology. In these stories the monster is sometimes called the name. The Leviathan is a monster in Babylonian mythology. The Bible also mentions the Leviathan as a monster. Thomas Hobbes also gave the names of the two monsters as title to their two works. These two monsters appear in the Bible. This article will focus on the meaning of the monster, in mythology, in the Bible and in the general public law (Thomas Hobbes).

Keywords: General Public Law, Thomas Hobbes, Leviathan, Behemoth, Rahab.

\footnotetext{
1 Karadeniz Teknik Üniversitesi, Hukuk Fakültesi, adilsahin@ktu.edu.tr, orcid.org/0000-00030019-2172.

2 Karadeniz Teknik Üniversitesi, İİBF, Kamu Yönetimi Bölümü, atiladogan@ktu.edu.tr, orcid.org/0000-0001-9331-5981.
} 


\section{Giriș}

Çok sayıda eser vermiş olan ünlü İngiliz genel kamu hukuku ve siyaset bilimi düşünürü Thomas Hobbes (1588-1679), Kitab-1 Mukaddes'in Eski Ahit bölümünden ilham alarak bir yapıtına "Leviathan", bir başkasına ise "Behemot" başlığını koymuştur. Kitab-1 Mukaddes'in Eski Ahit bölümünde ifade edilmiș olan Leviathan ve Behemot birer canavardırlar ve esasında yalnız da değildirler; çünkü Leviathan'ın ve Behemot'un ifade edilmiş olduğu kaynak, bir de "Rahav" adlı canavara yer vermektedir. Fakat Hobbes'un, hemen hatırlatalım, "Rahav" adlı bir eseri yoktur.

"İyi bir devlet nasıl olmalıdır?" sorusunun yanıtını aradığı eseri olan Leviathan'da Hobbes, "mutlak monarşiyi" (devleti tek kişinin yani kralın yönetmesini) savunmakta, toplumu kralın yönetmesinin gerekliliğini ispat etmeye çalışmaktadır. Behemot adlı eserinde ise Hobbes, İngiliz iç savaşını ve toplumsal düzenin savaş kaynaklı kaotik yapısını incelemekte ve yine iktidarın tek elde toplanması gerekliliğine dikkat çekmektedir. Hobbes, kelimenin tam manasıyla bir "devlet bilimi" düşünürüdür. Bu noktada akla gelmesi kaçınılmaz olan soru şudur: "Bir devlet düşünürü olan Hobbes, iki eserine birer canavarı (Leviathan ve Behemot) ifade eden başlıkları niçin koymuștur?" "İyi bir devlet" ile İngiliz iç savaşının; canavarlar ile nasıl bir bağlantısı/ilișkisi vardır? Anlamsal olarak "canavar", "iyi bir devlet" ve İngiliz iç savaşını hangi yönüyle/özelliğiyle ifade etmektedir? İşbu makalenin yazılmasının saiki, bahsi geçen bu sorular olmuştur.

Bir canavar türü olarak Leviathan ibaresi, ilk defa Kitab-1 Mukaddes'in Eski Ahit bölümünde kullanılmış değildir. Leviathan terimi ilk kez, bir mit olan Babil Yaratılış Destanı'nda (öteki adıyla Enuma Eliș öyküsünde) kullanılmıștır. Yani, Leviathan bir canavar olarak ilkin Babil Yaratılıș Destanı'nda, ikincil olarak Kitab-1 Mukaddes'in Eski Ahit bölümünde geçmektedir.

Ad1 "Leviathan" olmamakla birlikte, canavar imgesinin pek çok toplumun mitlerinde de kullanıldığını biliyoruz. Hatta ilk uygar toplumu kurmuş olan Sümer mitlerinde bile canavar olgusuna yer verilmiştir. O halde, mitolojik anlatılarda ilk uygar toplum olduğu kabul edilen/varsayılan Sümerlerden beri kullanılmakta olan canavar motifinin Sümerlerden Babillere geçtiğini hatta Babil uygarlığının bir kabilesi ve uzantısı olan İsrailoğulları'nın kutsal kitabında bile yer aldığı bilinmektedir. Sümerlerde, Babillerde ve Kitab-1 Mukaddes'te kullanılan canavar imgesi, ek olarak bir de bu "canavarın bir kahraman tarafindan yok edilmesi" anlatısıyla birlikte sunulmaktadır. İște, tam da bu noktada, ișbu yazının yanıtını arayacağı soruların sayısı da artmaktadır. Yukarıda, bu makalenin temel sorusu belirtilmiști; fakat șimdi bu sorulara yenilerinin eklenmesi gerekecektir. İkinci soruyu, dolayısıyla bu makalenin çözümünü aradığı ikinci problemi "Sümerlerde ve Babillerde canavar ve canavar öldürme motifi hangi anlama gelir?"; üçüncü problemi "Kitab-1 Mukaddes'in Eski Ahit bölümünde Leviathan (yani canavar ve öldürülmesi) hangi anlama gelir?" ve nihayetinde dördüncü ve sonuncu problemi de "Hobbes'ta Leviathan (canavar) hangi anlama gelir?” şeklinde netleştirebiliriz.

Anılan soruların yanıtının bulunabilmesi amacıyla kavramsal analizden sonra, ilkin, canavar ve canavar öldürme öyküsüne yer veren (beş adet olan) Sümer mitleri; ikinci 
olarak (üç adet olan) Babil mitleri ve üçüncü olarak da Kitab-1 Mukaddes'in Eski Ahit bölümü incelenmiş ve anılan öyküler analiz edilmiş; nihayetinde son olarak ise Hobbes'ta Leviathan (canavar) ibaresinin anlamı üzerinde durulmuştur. Gözlemlenen, canavar ibaresinin, Sümerlerde özellikle "tanrıların gücü"; Babillerde "tanrıların ve insanların gücü"; Kitab-1 Mukaddes'te ise yine aynen Sümerlerde de olduğu üzere "Tanrının gücü"; Hobbes'ta ise, Tanrı'dan sonra "ikinci en güçlü olan devletin gücü" (veya bir başka söyleyişle kralın gücü) anlamına gelmekte olduğudur. Dolayısıyla her halükarda, canavar motifi, "gücü” veya diyebiliriz ki "iktidarı" (esasında egemenlik kavramını) anlatmak için kullanılmış olan bir metafordur. Fakat zaman içerisinde bu iktidar/güç ilahi boyuttan beşeri boyuta kaymış, son tahlilde ise kralın iktidarı olarak açığa çıkmıştır.

Canavar yaratık olgusunun Thomas Hobbes ekseninde genel kamu hukuku disiplinindeki anlamının ortaya konulması amacıyla yazımına girişilen bu makalede üzerinde durulacak olan konu, bizi "mitolojik öykülerin incelenmesiyle işe başlanması" gerekliliğine götürmüştür. Bu bağlamda, inceleme alanımız da, doğal olarak sınırlandırılmıştır. Sümer ve Babil mitlerinden sadece canavar ve canavarın öldürülmesini içerenler incelemiştir ki anılan bu öykülerin sayısı da toplamda sekiz adettir. Kitab-1 Mukaddes ise Eski Ahit bölümünün incelenmesiyle sınırlandırılmıştır; çünkü Leviathan ve Behemot terimi, sadece Eski Ahit bölümünde geçmektedir. İlgilisine hatırlatılması gereken bir konu da, bir olgu olarak canavarın, Kitab-1 Mukaddes'in Yeni Ahit bölümünde de dillendirildiğidir; fakat Hobbes, Leviathan ve Behemot terimlerinin kullanımını tercih ettiğinden, anılan terimleri içermeyen Yeni Ahit, bu makalenin kapsama alanına dahil edilmemiştir. Nihai tahlilde, olası okuyucunun, bu makalenin iddiasına ilişkin çıkarılan sonuçların Sümer ve Babillere ait olan sekiz efsaneye, Kitab-1 Mukaddes'in Eski Ahit bölümüne ve Thomas Hobbes'un Leviathan ve Behemot adlı eserlerine ait olarak ortaya konulduğuna dikkat etmesi gerekir.

\section{Kavramsal Çerçeve}

\subsection{Mit ve Mitoloji}

Kelime olarak mit (Büyük Larousse, 1993: 8227); mitos, hikaye, anlatı ve efsane ifadeleriyle eş anlamlı olarak kullanılmaktadır. Mit, "doğaüstü varlıkları ve hayali olayları konu alan ve bir halkın yaşadığı olayların ya da o halkın aile düzenini ve toplumsal ilişkilerini temellendiren yapıları, düşsel bir hale getirerek yansıtan halk veya edebiyat anlatısı" olarak tanımlanabilir. Doğaüstü kişileri konu alan mitlerin ise her zaman dinle bir ilişkisi vardır ve tanrılara uygun görülen yaşamı, imgeler aracılığıyla somutlaştırmak ve tanrılarla ilgili inançları ve ayinleri temellendirmek olanağ 1 sağlarlar. Bir kültüre ait olan mitler, aynı zamanda, o kültürün değerlerini, örf ve adetlerini, geleneklerini ve aidiyetlerini yansıtma eğilimindedirler (Leeming, 2017: 103).

İlkel toplumların kendilerini ifade ettikleri psikolojik benzetmeler (Leeming, 2017: $11,15,21)$ olan mitler; Batı dünyasında hali vakti yerinde olan ailelerin çocuklarının okulda aldıkları "klasikler eğitiminin" önemli bir kısmını oluşturmuştur. Ak1l, "gerçekdışı" olduğunu söylediği halde, genel kabul görmüş olan bir inanç şekli olan 
mitler, genelde tanrıları ve kahramanları özne olarak sunan öykülerdirler. Mitlerin, konularına göre, "yaratılış mitleri", "tanrı mitleri" ve "kahramanlık mitleri” olmak üzere farklı çeşitleri bulunmaktadır.

$\mathrm{Bu}$ noktada öncelikli olarak belirtilmesi gereken konu, mit yaratıcılarının amacının "çekici, canlı ve de eğlendirici öyküler oluşturmak" olduğudur. Yani, zihne yönelik kanıtlamaları ve çıkarımları düşünmeyen mit yaratıcıları, öncelikle, "heyecan uyandıran öyküler" anlatmak ve de anlatabilmek derdinde olmuşlardır (Kramer, 2016: 109). Dolayısıyla bu Yazıda üzerinde durulacak olan konunun (canavar yaratık olgusunun ve algısının) bir öykü, yani mit olduğunu, "akılda tutulması gereken ilk yol gösterici” olduğunu özellikle vurgulayalım.

Yunanca, masal ya da hikaye demek olan mytos ile; söz anlamına gelen logos kelimelerinden birleştirilerek oluşturulan mitoloji (Can, 2015: 17; Leeming, 2017: 16) ise, "eski zamanlarda yaşamış olan toplulukların inandıkları tanrıların, kahramanların ve canavarların maceralarından bahseden hikayeler" anlamına gelir. Değişik bir söyleyişle mitoloji, sözü edilen bu efsanevi hikayelerin nasıl doğduğunu, hangi şartlarda üretildiğini inceleyen bilim dalıdır.

\subsection{Canavar, Ejderha ve Yılan}

Mitolojide yaygınlıkla karşılaşılan bir olgu, "canavar yaratık" ve bu "canavar yaratığın bir kahraman tarafindan öldürülmesi" anlatısıdır. Masal ve efsanelerde adı geçen, birkaç hayvanın özelliğini aynı anda üzerinde taşıyan ya da yarı insan yarı hayvan gerçek dışı yaratık olan "canavar" (Büyük Larousse, 1993: 2162; Campbell, 2015a: 69), insan için tehlikeli olabilen hayvanlara, özellikle kurt, domuz ve yılana verilen addır. İnsanoğlu, ürettiği efsanelerde canavar yaratıklar icat etmekten her zaman hoşlanmıştır. Meksika'da "tüylü yılanlar"; Çin'de ejderhalar; Mısır'da karaleylek, atmaca, kurt ya da öküz başlı tanrılar; Asur'da kanatlı boğalar ve Eski Yunanistan'da kötülük güçlerini ya da çeşitli doğa öğelerini simgeleyen çok sayıda canavardan, en azından mitlerde bahsedildiğini biliyoruz. Özellikle su canavarları, denizlerin ve deniz diplerinin korku, bilinmezlik ve karanlık anlamına gelmesi bağlamında mitolojide en korkulan canavarlar kategorisi olarak anılmaktadırlar.

Yarı insan yarı boğa canavarlar, köpek başlı tanrılar, kurt adamlar, insan başlı atlar ve deniz canavarları mitolojide yaygınlıkla karşılaşılabilen canavar yaratık (Dell, 2014: 6-8, 10, 20, 154-157) türleridirler. Düzen ve kaos arasındaki savaşı ya da iyi ve kötü arasındaki savaşı, tanrılar ve canavarlar aracılığıyla somutlaştıran toplumların her birinin de kendine özgü canavarları bulunmaktadır. İçimizdeki ötekini temsil eden canavarların öldürülmesinden sorumlu olan bir kahraman ve kahramanlık öyküleri ise her kültürde vardır. Mitolojide yaygın olarak karşılaşılan bir öykü çeşidi olan canavar öldürme ritüelinin (Leeming, 2017: 229-335) "içten ve diştan gelen tehditleri yok edebilmek" anlamına geldiğini söyleyebiliriz. Canavarı öldüren kahraman, içeriden ya da dişarıdan gelen tehlikeleri önlemekte; yani kaos çıkmasına engel olmakta ve de toplumun düzenli yapısının oluşturulmasına katkı sunmuş olmaktadır. Bu açıdan bakıldığında canavar öldürme öyküsünün bir yönüyle zorunlu olduğunu da tespit edebilmekteyiz; çünkü toplumsal yaşamın olmazsa olmaz koşulu kamu düzeninin 
sağlanmasıdır. Modern toplumlarda düzenin sağlayıcısı ise "devlet" olmuştur ve de devlet bu rolünü sürdürmektedir.

Farsça bir kelime olan ejderha (Büyük Larousse, 1993: 3566) ise, kısaca "ejder" olarak da ifade edilmektedir. Kanatları ve kuyruğu olan, yılan biçiminde, ağzından alevler püskürten, aslan pençeli bir masal yaratığı şeklinde betimlenen ejderha, "büyük yılan" olarak da anılmıştır. Eski dilde "ejderi kahir" ölüm ejderhası anlamına gelir; "ejderi münakkaş" ise nakışlı ejderha veya "alaca derili yılan" olarak ifade edilmektedir. Ejderha, köken itibarıyla en eski canavarlardan birisidir. İnsanoğlu, ejderhalara ve sürüngenlere karşı fakat özellikle de yılanlara karşı her dönem büyük bir korku ve endişe içinde olmuştur (Dell, 2014: 68). Öte yandan ejderha, gizli ve dışa vurulmayan güçlerin simgesi (ve hatta iblisin simgesi) olarak da düşünülmektedir. Eski insanlar, bir tutulma anında, ay yörüngesinin dügüumleri yakınında pusuya yatan bir ejderhanın, Ay'1 yuttuğunu düşünüyordu.

Ejderha ve yılan, dinler tarihinde de karşılaşılan bir olgudur. Dinler tarihinde Hz. Musa'nın yetiştirdiği yılana (Büyük Larousse, 1993: 12553-12554) “Tunç Yılan" denilmektedir. Yehova'ya iman etmeyen İbraniler, Hz. Musa'nın yetiştirdiği bu yılana baktıkları zaman iyileşirlermiş. Yaşamın ve bağlantılı olarak ölümün, gece değerlerinin ve dolayısıyla 1şığın ve de erkekteki dişilin simgesi olan yılan, YahudiHıristiyan gelenekte ise şeytanla bir tutulmuştur. Haham geleneğinde "Tekvin Yılanı", "kolları ve bacakları olan" ve tarih öncesi "kertenkele cinsinden büyük bir yılan” olarak kabul edilmiştir. Canavar (ejderha) ibaresi Kitab-1 Mukaddes'in ${ }^{3}$ hem Eski Ahit ${ }^{4}$ bölümünde, hem de Yeni Ahit bölümünde yer verilmiş olan yaratık türleridirler. Fakat bu çalışmada canavar ejderha ${ }^{5}$ bağlamında özellikle Kitab-1 Mukaddes'in Eski Ahit bölümü üzerinde durulmaktadır; çünkü konumuz olan Leviathan, Eski Ahit eksenindeki bir canavardır.

\footnotetext{
${ }^{3}$ Kitab-1 Mukaddes, Hıristiyanların dini alanda otorite kabul ettikleri, Yahudilerin kutsal kitabını da kapsayan yazılar koleksiyonuna verdikleri isimdir. Batı dillerinde Kitab-1 Mukaddes'in karşılığı "bible" kelimesidir. "Bible" kelimesini terim anlamında ilk kullananlar Hıristiyanlar olduğu için herhangi bir niteleme sıfatı olmaksızın tek başına kullanıldığında Eski Ahit ve Yeni Ahit’ten oluşan bütünü ifade eder. Kitab-1 Mukaddes'in ilk bölümünü Yahudi kutsal kitabı olan Eski Ahit oluşturur. Yahudiler, Eski Ahit'in orijinal dili olan İbranice nüshasını, Hıristiyanlar ise M.Ö. 3-1 yüzyıllarda yapılan Yunanca tercümeyi esas kabul etmektedirler. Kitab-1 Mukaddes'in sadece Hiristiyanlara ait olup Yahudiler tarafindan kabul edilmeyen ikinci bölümüne de Yeni Ahit denilmektedir (Kitab-1 Mukaddes konusunda ayrıntılı bilgi için bkz., Harman, 2002: 75-76).

${ }^{4}$ Hıristiyanlar, Yahudilerin kutsal kitabına Ahd-i Atik (Eski Ahit) demektedirler. Onlara göre, Tanrı ile insanlar arasındaki son ahid, Hz. İsa vasıtasıyla yapılmış olandır. Daha önceleri Tanrı ile İsrailoğulları arasında yapılan ahdi ihtiva eden metinlere Ahd-i Atik deniliyor. Yani Ahd-i Atik (Eski Ahit) Yahudi kutsal kitabıdır. Eski Ahit İbranice yazılmıștır. Eski Ahit’i teșkil eden bölümler, tarihin belli bir döneminde ve aynı anda yazıya aktarılmış değildir. Uzun süre şifahi olarak nakledilmişler; asırlar sonra kaleme alınmışlardır. Şifahi geleneklerin yazıya aktarılması M.Ö. 10. Yüzyılda başlamış, M.S. I. yüzyılda sona ermiştir. Esasen İsrail tarihinin ilk dönemlerinde şifahi gelenek hâkimdir. Eski Ahit, Hıristiyanlar tarafından da kutsal sayılmaktadır (Eski Ahit konusunda ayrıntılı bilgi için bkz., Harman, 1988: 494-501).

${ }^{5}$ Kitab-1 Mukaddes'in, sadece Hıristiyanlara ait olan ikinci kısmına Yeni Ahit denilmektedir. Eski Ahit, hem Yahudilerin hem de Hıristiyanların kutsal kitabı olduğu halde, Yeni Ahit sadece Hıristiyanlar tarafindan kutsal kabul edilmektedir. İsrailoğulları, Tanrı'nın kendileriyle yaptığı sözleșmeyi bozunca, Tanrı onlara Yeremya vasıtasıyla yeni bir sözleşme vaat etmiştir. Hıristiyanlara göre ise bu Yeni Ahit, Hz. İsa vasıtasıyla yapılmıştır. Hz. İsa Aramice konuştuğu halde, yeni Ahit Grekçedir (Yeni Ahit konusunda ayrıntılı bilgi için bkz., Tanyu,1988: 501-507).
} 
Orta Amerika'nın önemli bir mitolojik figürü olan (Azteklerdeki) "quetzalcoatl" (tüylü yılan) en çok korkulan mit canavarı olarak kabul edilmektedir (Dell, 2014: 14; Leeming, 2017: 321); çünkü yılanlar, yeryüzünden gelen gizemli ve korkunç gücün sembolleridirler. Mitolojide yaygınlıkla görülen bir olgu olan yılan motifi (Campbell, 2015a: 143, 200-201, 381, 426; Campbell, 2015: Cilt: III, 17-18, 20, 456; Campbell, 2015: Cilt IV: 24, 112-114, 173; Gürkan, 2013: 527-529) de vazgeçilmezdir; çünkü yılanın rolü bazen yılan balığınca, bazen de kertenkele tarafından oynanır ve her daim oynanır; yılan imgesinden vazgeçilmez. Evrenin ve bireyin enerjisini ve özünü besleyen güç, mitolojide yılan imgesiyle canlandırılmıştır. Esasında yılan motifi mitolojide sonsuz yaşamın simgesidir. Yılanın şaşılası biçimde derisini değiştirme yeteneği ve akabinde de gençliğini yenilemesi, yılana tüm dünyada "yeniden dünyaya gelme yeteneğinin ve gizinin ustası" niteliğini kazandırmıştır. Yılanın semavi işareti ise büyüyen ve solan görüntüsünü yok eden ve yine büyüyen bir gök cismi olan Ay'dır. Aynı zamanda "suların ilahı" da olan yılanın, mitolojide tanrısal bir rolü de vardır; çünkü yılana tapılır. Yılanın tanrı olarak resmedildiği pek çok eski eser de bulunmuştur. Kanatlı yılan veya iki kanatlı ejderha motifleri mitolojide yaygınlıkla kullanılan simgelerdir. Bu yazıda ilerleyen kısımlarda üzerinde durulacak olan Babil tanrıçası Tiamat da, Kitab-1 Mukaddes'in Eski Ahit bölümünde geçen Leviathan da yaygınlıkla bir deniz yılanı ya da ejderha olarak tasvir edilmektedir.

\section{Mitolojide Canavar Yaratık Olgusu: Sümerler'den Babiller'e}

Kavramsal çerçeveyi bu şekilde çizdikten sonra, artık "canavar yaratık" olgusunun tarihsel geçmişine göz atmaya başlayabiliriz. Canavar yaratık olgusunun tarihsel geçmişine göz gezdirmek ise, bizi, insanlık tarihinde ilk uygar toplumu kurmuş olan Sümerler dönemine kadar geriye taşımaktadır; çünkü Sümer miti, canavar yaratık olgusunu içermekte ve de dillendirmektedir. Sümerlerde canavar yaratık olgusuna geçmeden önce de Sümerler hakkında kısa bir bilgi verilmesi konunun anlaşılırlığ bakımından, elzem gözükmektedir.

\subsection{Sümerlerde Mitolojik Canavar yaratık Olgusu}

İnsanoğlunun "üretici geçim biçimine" dünyada ilk kez, ortalama M.Ö. 10 bin dolaylarında Batı Asya' da geçmiş olabileceği düşünülmektedir (McNeill, 2003: 19; Şenel, 2006: 357-358). Batı Asya'nın doğu Akdeniz kıyılarından Orta Asya'ya uzanan yabanıl tahıl bölgelerinin bir yerlerinde, bitkilerin ve hayvanların evcilleştirilmiş olabileceği dillendirilmektedir.

Uygarlığın ise ortalama M.Ö. dördüncü binyılın sonunda, Sümer denilen Dicle ve Fırat nehirleri ortasında, Aşağı Mezopotamya'da başladığı bilinmektedir. Yani uygar topluma ortalama beş binyıl önce geçilmiştir (Roberts, 2011: 50, 59; McNeill, 2003: 20, 34, 37; Şenel, 2006: 325, 345, 363). Medeniyet veya uygarlık terimlerinin etimolojik kökeni "kentli yaşayış biçimi" anlamına gelmekte; kentli yaşayış biçimine ve kültürüne ulaşmamış topluluklar için ise uygarlık sözcüğü yerine "kültür" kelimesi kullanılmaktadır (Şenel, 2006: 326). Bu bağlamda insanlığın başlangıcı ile uygarlığın başlangıcı farklı kavramlar ve dönemler olarak karşımıza çıkmaktadır. Kaldı ki, 19. yüzyıla dek, zaten ilk uygarlık denilince akla gelen Eski Yunan olmuştur. 19. Yüzyılda ise, insanlığın en eski uygarlığının Mısır olduğu sanılıyordu. Yani, Hititlerin 
varlığı ve Anadolu'da parlak bir uygarlığın kurucusu oldukları ancak 19. Yüzyılın sonlarına doğru anlaşılabilmiştir. Başka bir ifadeyle belirtirsek, insanlığın uygar topluma ilk olarak M.Ö. dördüncü binyılda Sümer denilen Aşağı Mezopotamya'da geçtiği, ancak 20. yüzyılın başında kesinleşmiştir (Şenel, 2006: 357).

Öte yandan Sümerlerin, Sümer denilen Aşağı Mezopotamya'ya gelişlerinden önceki yaşamları ve hatta kim oldukları, nereden geldikleri henüz kesin olarak tarihin karanlıklarından çıkarılabilmiş değildir (Şenel, 2006: 358). Bu şekildeki bir bilinemezcilik yaklaşımının arkasında yatan saik şöyle izah edilebilir: Aşağı Mezopotamya topluluklarının dillerinin Sami kökenli olmasına karşılık, Sümerce bir Sami dili değildir. Dil bilginleri, Sümerceyi, bilinen bir eski dil ailesine sokabilmiş değildirler. Anılan durum, Sümerlerin yöre halkından olmayıp dışarıdan geldiklerini gösteren bir olgu olarak değerlendirilmektedir (Kramer, 2014: 29, 52; Şenel, 2006: 359). Sümerlerden kalan kil tabletler üzerindeki resimlerde de, Sümerlerin, kendilerini "sakalsız ve traşılı" olarak göstermelerine karşılık, karşılarındaki kişileri (muhtemelen Sami halkını) "saçlı ve sakallı" olarak tasvir ettiklerini tespit edebiliyoruz.

Hemen hatırlatalım ki Sümerler, sayı ve yazı sistemlerinin de ilk kurucusu olmuşlardır (Şenel, 2006: 372). M.Ö. üçüncü binyıldan itibaren de (hatta dördüncü binyıldan itibaren olduğunu söyleyenler de vardır), yazının, Sümerler tarafından kullanıldığg düşünülmektedir (Gılgamış Destanı, 2016: VII; Şenel, 2006: 423; McNeill, 2003: 39; Kramer, 2016: 13). Fakat alfabetik yazının temellerini atan Sümerler değildir. Filistin (Kenan ülkesi), Mezopotamya ve Misır uygarlıkları arasında kalmış bir ülkeydi. Bu nedenle ve deniz kıyısındaki konumuyla da yoğun alışveriş etkinliklerinin gözlemlenebildiği bir bölgeydi. İşte sözü edilen bu Filistin adlı bölgede, M.Ö. ikinci binyılın ilk yarısında (milattan önce 1600 dolaylarında) Sami dili konuşan Kenanlı tacirler alfabetik yazının temellerini atmışlardır (Şenel, 2006: 376, 424). M.Ö. dördüncü binyılın sonuna doğru (yani M.Ö. üçüncü binyılın başlarından itibaren) kil tabletler üzerine yazma düşüncesine sahip olduklarına inanılan Sümerlerin, yazıyı kullanmış olmalarına rağmen, sistematik bir felsefe geliştiremedikleri iddia edilmektedir (Kramer, 2016: 13, 104).

İnanç boyutuyla bakıldığında ${ }^{6}$, Sümerlerin çok tanrı inancına sahip olduklarını gözlemleyebiliyoruz. Gözle görülmeyen, insan biçimli olan ancak insanüstü ve ölümsüz varlıklara inanan Sümerler, bunlara dingir (yani tanrı) ismini vermişlerdir. Sümerlere göre tanrılar, insanı da kendi görünüşünde yaratmışlardır. Sümer inanışına göre yazgıları belirleyen yedi tanrı ve büyük tanrılar olarak bilinen elli tanrı vardı. Örneklendirirsek; gök tanrısı An, hava tanrısı Enlil, su tanrısı Enki ve büyük ana tanrıça Ninhursag sözü edilen bu tanrılar arasında sayılmaktadır. Kendilerinin "tanrılar tarafından seçilmiş özel bir millet" olduğunu düşünen Sümerlerin döneminden kalan kil tabletlerde "tanrıdan haber almanın", "tanrı ile görüşmenin (yani başka bir söyleyişle peygamberliğin de)" Mezopotamya'da başladığını öğrenebiliyoruz.

\footnotetext{
${ }^{6}$ Sümerlerde inanç konusunda bkz., Kramer, 2016: 107 ve 119; Çı̆̆, Kuran, İncil ve Tevrat'ın Sümer'deki Kökeni: 19, 31 ve 46; Çı̆̆, İbrahim Peygamber: 139 ve 143.
} 
Pek çok miti ${ }^{7}$ olan Sümerlerin, destansı masallarından en az dokuzu orijinal hale getirilebilmiştir. Anılan bu destanlardan altısı büyük Sümer kahramanları Enmerkar, Lugalbanda ve Gılgamış’ın yiğitliklerinin anısına yazılmıştır. $\mathrm{Bu}$ üç Sümer kahramanının M.Ö. dördüncü binyılın sonuna doğru (Yani M.Ö. üçüncü binyılın başlarından itibaren) yaşamış oldukları tahmin edilmektedir. Anılan dokuz Sümer destanından geriye kalan üçü ise bir canavarın (Sümer dilindeki ifadesiyle Kur'un) yok edilmesiyle ilgilidirler (Kramer, 2014: 39). Canavar derken, sözü edilen bu canavarın Babillerin Babil tanrıçası TİAMAT'ına; İbranilerin Leviathan'ına ve Yunanlıların Typhon'una karșılık geldiğini de belirtelim. Yani, canavar yaratık ve bu canavarın öldürülmesi diğer bütün kültürlerde ve bütün kültürlerin mitlerinde de kendisine yer bulur.

Canavar ibaresi Sümercede bazen $\mathrm{Kur}^{8}$ kelimesiyle de ifade edilmektedir. Sümercede Kur sözcüğünün ise çeşitli anlamları vardır. Kur sözcüğü, Sümer dilinde kelime olarak, "dağ”, "yabancı ülke", "ülke”, "ölüler diyarı", "kozmik olarak yer kabuğu ile ilksel deniz arasındaki boş alan" ve "dipte yaşayan korkunç yaratık" gibi anlamlara gelmektedir. Dolayısıyla şu notu da ekleyelim ki, Sümercede Kur, "korkunç bir canavarı (ejderhayı)" betimler gibi gözüküyor.

İnsanoğlunun kültürel birikimi dikkate alındığında kolaylıkla gözlemlenen olgu, mitolojide yaygın bir "canavar yaratık öldürme" anlatısının bulunduğudur. Başka bir söyleyişle, canavar öldürme motifinin Mezopotamya mitleriyle sınırlı kalmadığının da altı çizilmelidir. Hemen her çağda her halkın kendi canavar (ejderha) öyküleri olmuştur. Özellikle Yunanistan'da ejderha öyküsü bolca vardır. Herakles ve Perseus'un en çok tanınan ejderha öldürenler olmalarına karşıllk, ejderha öldürmeyen bir Yunan kahramanı neredeyse yok gibidir' Hıristiyanlığın yükselişiyle birlikte, canavar öldürmeyle somutlaşan bu kahramanlık göstergesi azizlere (din adamlarına) bile geçmiştir ${ }^{10}$. Canavar (ejderha) öldürme temasının M.Ö. üçüncü binyılda Sümer mitolojisinin önemli bir motifi olduğunu dikkate alırsak, Sümerler dışındaki öteki toplumların öykülerinin Sümer'den etkilenilerek anlatılmıș olduklarını da kolaylıkla söyleyebiliriz (Campbell, 2015a: 18-19; Kramer, 2014: 143-144; Kramer, 2016: 211).

Tarihin bilinen ilk uygarlığını kurmuş olan Sümerlerde canavar yaratık konusuna gelirsek, esasında bir canavarın öldürülmesini içeren özgün bir Sümer öyküsünün olmadığını görüyoruz. Yani, Sümerlerde, salt canavar öldürme motifiyle kuşatılmış

\footnotetext{
${ }^{7}$ Bottero ve Kramer, 2017.

${ }^{8}$ Sümerlerde “Kur"un anlamı konusunda bkz., Kramer, 2014: 142; Kramer, 2016:. 210.

${ }^{9}$ Canavar yaratık öldürme olgusu konusunda; Herakles'in, Nemea Aslanını ve dokuz başlı korkunç ve kocaman bir su yılanı olan Lerna Hydrası'nı öldürmesi; Theseus'un, insan vücutlu boğa başlı bir canavar olan Minotor'u öldürmesi; Odysseus'un, tek gözlü dev olan Kykloplar ve kuş bedenli kadın canavarlar olan Sirenler ile mücadele etmesi; Perseus'un, deniz canavarlarını ve yılan başlı ve kanatlı bir canavar olan Medusa'yı öldürmesi; Kadmos'un, su pınarını koruyan insan yiyen yılanı öldürmesi; Oidipus'un yarı kadın yarı kanatlı aslan olan Sfenksleri öldürmesi önemli örneklerdir (Yunan mitinde canavar ve canavar öldürme olgusu konusunda ayrıntılı bilgi için bkz. Burn, 2017: 23-35, 37-46, 65-87, 82-95, 97-101, 103-105 ve 107 108; Can: 196-204, 217-219, 224-226, 229-230 ve 240-242; Leeming, 2017: 74-75, 85, 90, 110-113 ve 115 116; Dell, 2014: 160).

10 Aziz George'un, ejderhayla olan mızrak dövüşü; Azize Marta'nın, Tarasque adlı azgın canavarı uysallaştırması, Hıristiyanlığın yaygınlaştııılmasına ilişkin olan mitlerdir (Azizlerde canavar öldürme olgusu konusunda bkz., Dell, 2014: 7-8).
} 
olan bir efsane yoktur; fakat Sümer mitlerinden beşinde canavar öldürme öyküsüne, az da olsa yer verilmiştir. Dolayısıyla, aslında, Sümerlerde canavar öldürmeyle ilgili olan ve elimizde bulunan beş mit de konumuzla ilgilidirler ve bu yüzden de bu makalenin inceleme kapsamına dahil edilmişlerdir. Başka bir söyleyişle ifade edersek, M.Ö. üçüncü binyılda Sümer'de geçerli olan ejderha öldürme mitlerinden beşi elimizdedir. Birincisi, Sümer su tanrısı Enki'nin; ikincisi Sümer savaş tanrısı Ninurta'nın; üçüncüsü Sümer aşk ve mücadele tanrıçası İnanna'nın; dördüncüsü Sümer kahramanı Gılgamış'ın; beşincisi ise tanrı Tişpak'ın öyküsüdür. Her beş öyküde de, öldürülen yaratık "canavar" (ejderha ya da yılan) olarak anılır. Sözü edilen bu canavarın da derinliklerde yaşayan "büyük bir yılan" olduğuna dair göstergeler vardır. Çünkü canavar yok edildiği zaman sular yeryüzüne yükselmekte ve bunun sonucunda da yeryüzünde tarım yapmak olanaksız hale gelmektedir.

\subsubsection{Sümer Yaratılış Miti}

Sümerlere ait olan ve de canavar öldürme öykülerinden ilki olarak anılan "Enki ve canavar" miti, kendine özgü bir Sümer destanında anlatılmış değildir. Yani, inceleyecek olduğumuz destan, spesifik olarak bir canavar öldürme öyküsü anlatısı değildir. Su tanrısı Enki'nin canavarı öldürme öyküsünü, yine Sümerlere ait olan bir şiirin (destanın) sadece "giriş" kısmından öğreniyoruz. Sözü edilen bu Sümer şiirinin "giriş" kısmı hem Sümerlerin yaratılış mitini, hem de su tanrısı Enki'nin canavarı öldürmesini içeren bir bölümdür. Bu Yazıda önce, konunun bütünlüğü açısından, sözü edilen Sümer şiirinin "giriş" kısmında belirtilmiş olan Sümerlerin yaratılış miti üzerinde durulacak, sonrasında ise yine sözü edilen Sümer şiirinin "giriş" kısmında belirtilmiş olan su tanrısı Enki'nin canavarı öldürmesi öyküsü ve olgusu incelenecektir. Anılan Sümer şiirinin "giriş" kısmına göre, bir başka söyleyişle Sümerlere göre, evrenin yaratılışı miti şöyledir (Campbell, 2015c: 63; Kramer, 2014: 8-9, 12-13, 80-84, 87-88):

Sümer'de evrenin temel öğeleri “yeryüzü” ve “gökyüzü” olmuştur. Yeryüzü, “düz ve yassı bir disk"; gökyüzü ise "kubbe biçiminde katı bir yüzeyle örtülü çukur bir yer" olarak düşünülmüştür. Yeryüzü, yerin yüzeyinden ve "ölüm ve cehennem ilahlarının bulunduğu yerin altından" oluşan düz bir yuvarlaktı. Gökyüzü ve yeryüzü her taraftan "sonsuz bir deniz" ile kuşatılmıştı. Yani, "başlangıçta ilksel deniz vardı" inancına sahip olan Sümerler, sözü edilen "ilksel deniz" öncesini düşünmemişlerdir ya da düşünememişlerdir (Kramer, 2016: 105-106). Değişik bir ifadeyle belirtirsek, Sümer efsanesine göre evrende ilkin adı tanrıça Nammu olan büyük bir su kitlesi vardı. Tanrıça Nammu, anılan bu sudan (yani kendisinden), büyük bir dağ çıkardı. Tanrıça Nammu'nun oğlu olan hava tanrısı Enlil de bu dağı ikiye ayırdı. İkiye ayrılan bu dağın üst kısmı gökyüzü oldu; gök tanrısı (An) bu üst kısmını aldı. İkiye ayrılan dağın alt kısmı da yeryüzü oldu ve yer tanrısı (Ki) ile hava tanrısı (Enlil) de yeryüzünü aldı (Çı̆̆, 2017a: 45; Kramer, 2014: 12).

Sümer yaratılış mitine göre gökyüzü erkek; yeryüzü ise dişi idi. Bu ikisinin birleşiminden hava tanrısı Enlil doğmuştur. İşte, dağı ikiye ayıran anılan bu tanrı Enlil olmuştur. Hava tanrısı Enlil ile yeryüzü tanrısı Ki yeryüzünde kalmış; böylece evrenin düzeni, insanın yaratılışı ve uygarlığın kuruluşu başlamıştır. Hava tanrısı Enlil'in yeryüzünden, gökyüzünü ayırdıktan sonra ay tanrısı Nanna-Sin'e yaşam 
verdiği de mitolojik olarak açıklanmıştır. Sümer yaratılış mitinin muhtemelen M.Ö. üçüncü binyılda kurgulandığı düşünülmektedir.

Sümerlere ait olan bu şiirin (öykünün) Sümer yaratılış mitini anlatan "giriş" bölümünden şu vargılara ulaşılmıştır: Bir zamanlar gök ile yer birdi. Gök ile yerin ayrılmasından önce bazı tanrılar vardı. Gökyüzü ile yeryüzünün ayrımı sonrası gök tanrısı göğ̈̈ ele geçirdi, fakat yeri ele geçiren hava tanrısı Enlil oldu. Şiirin "giriş" kısmından anlaşılamayan bazı soruların yanıtı ise günümüze gelen diğer Sümer metinlerinden çıkarılmıştır. Anılan bu sonuçlar da şöyle belirtilebilir: Sümerler, gök ile yeri "ilksel denizin" yarattığı ürünler olarak kabul ediyor. "İlksel deniz" tanrıça Nammu'dur. Gök ile yere yaşam veren "ana", sözü edilen bu tanrıça Nammu olur. Yerden göğü ayırıp uzaklaştıran ise hava tanrısı Enlil olmuştur. Kısaca şöyle de izah edilebilir. Başlangıçta ilksel deniz vardı. İlksel denizin kökeni veya doğuşu konusunda Sümer efsanesinde bir șey söylenmemektedir. Sümerler, ilksel denizi her zaman varmış gibi düşünmüş olabilirler. İlksel deniz, gök ile yerin birliğinden oluşan kozmik dağı oluşturdu. Tanrılar insan biçiminde somutlaștırıldığında gök (An) eril; yer (Ki) dișildi. Onların birleșmelerinden hava tanrısı Enlil doğdu. Hava tanrısı Enlil yerden gögü ayırdı ve babası An göğü ele geçirirken, Enlil, annesi olan Ki'yi, yani yeryüzünü ele geçirdi. Enlil ile annesi Ki'nin birleşmesi de evrenin düzenlenmesini, insanın yaratılışını ve uygarlığın kuruluşunu başlattı. Yani, Sümer efsanesine göre iyi günlerin gelmesini sağlayan "hava tanrısı Enlil" olmuştur. Topraktan tohum çıkarmayı ve ülkeye bolluk getirmeyi aklına koyan, kazmaya ve sabana ilk şeklini veren de yine hava tanrısı Enlil'dir.

\subsubsection{Su Tanrısı Enki ve Canavar}

Sümerlere ait olan bir şiirin "giriş" kısmında hem Sümer yaratılış mitinin, hem de Enki’nin canavarı öldürme öyküsünün yer aldığını yukarıda belirtmiștik. Bir önceki başlıkta da Sümer yaratılış miti izah edilmeye çalışıldı. Şimdi, Sümerlere ait olan şiirin yine "giriş" kısmında anlatılmış olan Enki ve canavar öyküsüne geçebiliriz.

Sümerlerin canavar öldürme uyarlamalarından ilki olan "Enki ve canavar" öyküsü (Kramer, 2014: 144-146), aslında canavar öldürme mitlerinden en özgünü gibi görünmektedir. Çünkü ilk elde tanrı ve canavar arasındaki savaş, gökyüzü ile yeryüzünün ayrılmasından hemen sonra gerçekleşmiş gibidir. Dahası, işlenen suç, büyük bir olasılıkla bir tanrıçanın kaçırılmasıdır. Bilgelik tanrısı, Sümer'in yöneten ve yaratan tanrılarından biri olan su tanrısı Enki ise öykünün kahramanıdır.

Gökyüzü ile yeryüzü ayrıldıktan sonra gök tanrısı An gögü, hava tanrısı Enlil yeri ele geçirmiştir. Çirkin hareket bundan sonra gerçekleşir. Tanrıça Ereşkigal, canavar tarafından kaçırılıp ölüler diyarına götürülür. Bunun üzerine, önemli Sümer tanrılarından biri olan su tanrısı Enki, tanrıça Ereşkigal'in kaçırılmasının öcünü almak ve canavar ile savaşmak için bir gemiyle yola çıkar. Tanrıça Ereșkigal'i kaçıran canavar, irili ufaklı her türden taşla, Enki'ye zalimce karşılık verir; Enki'nin gemisine arkadan ve önden saldırır. Kazananın, olasılıkla Enki olduğunu söyleyebiliriz; çünkü bulunan kil tabletler kırık olduğu için öyküde belirsizlikler vardır ve öykünün akıbetini maalesef bilmiyoruz. 
Her ne kadar Enki ve canavar öyküsünün akıbetini kırık olan kil tabletler yüzünden bilemiyor olsak da, öykünün sonucunu tahmin etmek hiç de zor değildir; zafer, kuvvetle muhtemel, tabi ki Enki'nin olmuştur. Çünkü anılan öykü bir kahramanlık destanıdır ve kahraman olabilmenin yolu da, kahramanın gücünün büyüklügünün ve biricikliğinin vurgulanması bağlamında, canavarın öldürülmesinden (öldürülmüş olduğundan) geçmektedir. İkinci olarak, anılan Enki ve canavar öyküsünde, canavarın adının ve fiziksel özelliklerinin betimlenmemiş olduğuna da dikkatleri çekelim. Bahsi geçen canavarın fiziksel özelliklerini bilemiyor olsak da, ortada bir canavarın olduğunu ve Enki ile kıyasıya mücadeleye giriştiğini kolaylıkla gözlemleyebiliyoruz. İşbu anlatılan canavar öyküsü, elimizdeki bilgiler bağlamında, bilebildiğimiz kadarıyla, insanlığın ilk canavar öldürme öyküsüdür ve bahsi geçen hikaye Mezopotamya'da Sümerlerde geçmektedir. Bu yönüyle Sümerler hem ilk uygarlığın kurucusudurlar, hem de canavar öldürme mitosunun ilk üreticisi, anlatıcısı ve yazıcisidırlar.

Öyküde toplumun düzenini bozan, kaos çıkaran ve huzursuzluğun kaynağı olan bir "canavar" vardır. Canavarın kamu düzeninin bozucusu olması, tanrıça Ereşkigal'i kaçırmasından kaynaklanmaktadır. Tam da bu noktada, kahraman, önemli bir Sümer kahramanı olarak anılan su tanrısı Enki sahneye çıkar, rolünü oynar ve muhtemelen de tanrıçayı kurtarır. Bu yönüyle bahsi geçen öykü, tanrıların birer "kahraman" olduklarını, her şeye güçlerinin yetebileceğini ve kamu düzenini tek başlarına olsa da sağlayabileceklerini vurgulamakta ve topluma yüksek bir moral aşılamaktadır.

\subsubsection{Savaş Tanrısı Ninurta ve Canavar}

Canavar öldürme mitinin ikinci uyarlaması (Kramer, 2016: 213-215; Bottero ve Kramer, 2017: 383-425; Kramer, 2014: 148-151), Babillerin yaratılış destanında Sami düzeltmenler tarafindan büyük oranda esinlenilerek kullanılmış olan öykü olması bakımından da önemlidir. Öykünün kahramanı, Sümerlerde hava tanrısı Enlil'in oğlu olduğu düşünülen savaş tanrısı Ninurta'dır.

Öykü, tanrının silahlarının kişileştirilmiş biçimi olan Şarur'un, savaş tanrısı Ninurta'ya verdiği bir söylevle başlar. Şarur, sebebi bilinemeyen bir nedenden dolayı canavar düşmanıdır ve Ninurta'yı canavarla savaşıp, onu yok etmesi için kışkırtır. Ninurta söyleneni yapar; fakat başaramaz ve kaçar. Şarur, canavarın öldürülmesine ilişkin isteğini tekrarlar. Bunun üzerine Ninurta bütün silahlarıyla yeniden saldırır ve artık bu sefer canavarı öldürmeyi başarır.

Canavarın yok edilmesiyle de ülkede ciddi bir felaket başlar. Canavarın egemenliği altındaki "ilksel sular" yeryüzünü basınca, tatlı su, bahçelere ulaşmaz, Dicle'nin suları yükselmez, ırmak iyi su getirmez olur. Sonuç tam bir kıtlıktır. Bunun üzerine Ninurta, ölen canavarın üzerine taş yığarak, ülkenin önüne büyük bir duvar örer. $\mathrm{Bu}$ taşlar taşkın suları engelleyince, alt diyarların suyu artık yeryüzüne yükselmez olur. Ninurta da, ülkeyi kaplayan suları Dicle'ye akıtır ve nihayetinde tarlalar sulanır. Savaş tanrısı Ninurta'nın kahramanca başarılarını işiten annesi Ninmah'ın, oğluna olan sevgisi kabarıp, oğlunu görmek isteyince, Ninurta da annesine dünya gözüyle bakar. 
Anlatı, kırık tabletler yüzünden burada biter; dolayısıyla öykünün devamını ve ayrıntılarını bilemiyoruz. Fakat canavardan ve canavarın öldürülmesinden haberdar olmaya yetecek ölçüde elde tabletlerin olduğunu vurgulayalım.

"Savaş tanrısı Ninurta ve canavar" başlıklı öyküde, canavarın isminden ve fiziksel özelliklerinden bahsedilmez. Fakat anılan canavarın bir "su tanrısı" olduğu aşikârdır; çünkü sözü geçen canavar öldürüldügünde ülkeyi su basmıştır. Öyküde üzerinde durulan, ülkeyi kitlığa boğan bir sorunun çözümlenmesi olmuştur. Toplumun sorunu ileri derecededir; çünkü sadece su yoksunluğu değil; aynı zamanda kıtlık da, yani açlık sorunu da baş göstermiştir. Sorunun çözümlenmesi ve toplumun huzurunun sağlanması da yine bir kahraman tarafından gerçekleştirilir. Öyküdeki kahraman, savaş tanrısı Ninurta'dır. Tanrı Ninurta, toplumun su ve kıtlık sorununu zekasını kullanarak çözmüş; "kötülük" ve kaos toplumsal düzlemden uzaklaştırılmış, toplum huzura kavuşturulmuştur. Öyküde, bir sorunun çözümlenmesi, ikinci bir sorunu doğurmaktadır. İlk çözümlenen sorun canavarın öldürülmesidir. İkinci çözümlenen sorun ise, canavarın öldürülmesi üzerine ortaya çıkan sorunun halledilmesi olmuștur. Bir sorunun çözümlenmesi, başka bir sorunu tetiklerse, ikinci sorun da çözümlenebilir mesajı veren öykü, tanrıların gücüne atıfla tanrılara güvenilmesi mesajı vererek topluma moral aşılamaktadır.

\subsubsection{Aṣ̂ ve Mücadele Tanrıçası İnanna ve Canavar}

Aşk ve mücadele tanrıçası İnanna'nın canavar öldürme anlatısında (Bottero ve Kramer, 2017: 247-259; Kramer, 2014: 152-153), ejderhayı öldüren bir tanrı değil; tanrıçadır. Öyküde bahsi geçen İnanna, sadece aşk tanrıçası değil, aynı zamanda savaş ve mücadele tanrıçasıdır. İlahilerde tanrıça İnanna, "canavarın yok edicisi”" diye anılır.

İşbu anlatıda, tanrıça İnanna'nın talebi açıktır: İnanna'nın gücünden habersiz olan ya da İnanna'nın gücünü unutmuş olan canavar, tanrıça İnanna'ya boyun eğmedikçe, İnanna canavara karşı acımasız olacaktır. Nihayetinde tanrıça İnanna silahlarını alır; canavara saldırır ve onu öldürür. Öykünün devamını bilemiyoruz; çünkü ayrıntılı ve tam metni içeren kil tabletler, maalesef kırıktır.

Öyküde, canavarın adı ve fiziksel özellikleri ifade edilmemiştir. Canavarı öldüren ise bir "kadın"dır. Öykü, Sümerlerdeki ilk "canavar öldüren kadın" anlatısıdır ve bu yönüyle de orijinaldir. Öyküde kadınların da erkekler gibi kahramanca bir tavırla canavar öldürebileceğine; bir başka söyleyişle sorunları çözebileceğine yapılan bir vurgu söz konusudur. Fakat bahsi geçen "kadın" bir tanrıçadır ve nihayetinde kaosu ortadan kaldıran kadın, bir ilahtır. Bu bağlamda öyküde kadının rolünün ikincil olmadığına dikkat çekilerek de olsa, toplumsal sorunların yine tanrılar tarafından çözümlenebileceğine yapılan atıf ön plandadır. Tanrılara inanılması ve güvenilmesi vurgusunun açıkça kendisini belli ettiği öyküde, tanrıların gücünün unutulmaması gereği de ön plandadır.

\subsubsection{Sümer Kahramanı Gılgamış ve Canavar Yılan}

Büyük Sümer kahramanı Gılgamış’ın, “çekicilikten nasibini almamış yılan” olarak tasvir edilen canavarı öldürmesi miti (Leeming, 2017: 34-35; Kramer, 2014: 69-75) bir Sümer şiirinde yer alır. Sözü edilen Sümer şiirine göre anlatı şöyledir: 
Bir zamanlar, sularıyla beslendiği Fırat ırmağının kenarına dikilmiş olan bir huluppu (söğüt) ağacı vardı. Fakat güney rüzgarı olarak anılan bu huluppu ağacını kökünden sökünce, ağaç, ırmağın sularıyla sürüklendi. $O$ anda, oradan geçmekte olan gök tanrıçası İnanna ağacı alıp ana tapınağının merkezi olan Uruk şehrine götürdü ve kendi kutsal bahçesine dikti. Tanrıça İnanna ağacı büyütüp, kendisi için iskemle ve sedir yapmayı planlıyordu. Huluppu ağacının zaman içerisinde büyümüş olmasına rağmen, tanrıça İnanna üç engel yüzünden ağacı kesemedi; çünkü ağacın dibine, ilkin, "çekicilikten nasibini almamış yılan" yuva yapmıştı. İkinci olarak, $\mathrm{Zu}$ kuşu ağacın tepesine yavrusunu koymuştu. Üçüncü olarak, harabe hizmetçisi Lilit, ağacın dallarına evini kurmuştu.

Tanrıça İnanna'nın ağacı kesemeyişinden kaynaklanan yakınmalarını duyan büyük Sümer kahramanı Gılgamış, İnanna'nın yardımına koştu. Yirmi beş kiloluk zırhını kuşanan Gılgamış, iki yüz kilodan fazla olan yol açma baltasıyla ağacın dibindeki “çekicilikten nasibini almamış yılanı" öldürdü. Bunun üzerine Lilit ve Zu kuşu da kaçtı. Ağaç ise kesilip tanrıça İnanna'ya sunuldu. Kendisine sunulan ağaçtan bir davul (pukku) ve bir tokmak (mikku) yapan tanrıça İnanna, bunları ödül olarak Gılgamış'a verdi. Fakat Gılgamış, gezinirken davul ve tokmağı yer altındaki bir deliğe düşürdü. Böylece davul ve tokmak "ölüler diyarına" düşmüş oldu. Davul ve tokmağın ölüler diyarına düşmelerine sebep olan ise "genç kızların yakınışları" olmuştur.

Tanrıça İnanna'nın hediye ettiği davul ve tokmağı ölüler diyarına düşüren Gılgamış'ın, arkadaşı ve hizmetçisi olan Enkidu ise hemen sahibinin yardımına koşar. Gılgamış'ın arkadaşı Enkidu, davul ve tokmağı geri getirmek için ölüler diyarına iner. Fakat Enkidu ölüler diyarında tutsak alınır ve yeniden yeryüzüne çıkamaz. Gılgamış, bunun üzerine, Sümer baş tanrısı olan Enlil'e gider ve "Enlil baba" diye başlayarak başından geçenleri anlatır. Fakat Enlil, arkadaşı Enkidu'yu kurtarması için Gılgamış'a yardım etmekten kaçınır. Bu sefer Gılgamış su tanrısı Enki'ye gider. Enki ise güneş tanrısı Utu'ya “ölüler diyarında bir delik açmasını ve Enkidu'nun gölgesini yeryüzüne çıkarmasını" buyurur. Ölüler diyarında esir alınmış olan Enkidu'nun görüntüsü aniden yeryüzünde Gılgamışın önünde belirir. Heyecanlanan ve sevinen Gılgamış, Enkidu'ya "ölüler diyarında ne gördüğünü" sordu. Fakat tabletin geri kalan kısmı kırık olduğu için Gılgamış ile Enkidu arasındaki diyaloğun ayrıntısından maalesef haberdar değiliz.

Öyküde, Sümer toplumunun önemli ihtiyaçlarından birisi olan "kereste” vurgusu göze çarpmaktadır. Sümer toplumunun kereste ihtiyacının giderilmesinin önündeki engellere dikkat çeken öykü, kahraman olarak da Gılgamış'ı sahneye sürer. Fakat öyküyü özgün yapan, sorunların adedi olur. Çünkü öyküde kamu düzeninin sağlanmasının yani toplumun huzurunun gerçekleştirilmesinin önünde süper kahramanın çözmesi gereken üç farklı problem vardır. İlki, kadim "canavar" problemidir. Fakat bu kez öyküdeki canavar açıkça bir "yılan" olarak betimlenmektedir. Yılanın yani canavarın adı ve fiziksel özellikleri ise zikredilmemiştir. Sorunların ikincisi Zu kuşu, üçüncüsü ise Lilit olarak anılmaktadır. Sümer toplumunun kereste ihtiyacının giderilmesi için anılan üç sorun da Gılgamış tarafından çözümlenir; kaos ve huzursuzluk böylece ortadan kaldırılmış olur. Yani ön 
planda olan yine toplumun yararı için canavarın öldürülmesi anlatısı ve toplumun moralinin yükseltilmesi gerçeğidir. Öyküde üzerinde durulan ikinci konu ise ölümün bir hakikat olduğu, ölümden kaçışın mümkün olmadığı ve toplumun böyle bir sona kendisini hazırlaması gereği olduğu da söylenebilecektir; kaldı ki, bu sonuç da yine öykünün amacının toplumsal moralin yükseltilmesi olduğunu karşımıza çıkarmaktadır.

\subsubsection{Tanrı Tişpak ve Canavar Labbu}

İkinci dereceden bir tanrı olan Tişpak'ın canavar öldürmesi kurgusuna göre (Bottero ve Kramer, 2017: 527-533) dev bir ejderha (canavar) dünyayı yıkıp geçiyordu; fakat tanrılar sadece merak içinde bekleşiyor, olaya müdahale etmiyorlardı. Tanrılara göre, adı "Labbu" olan canavarı "deniz doğurmuş" olabilirdi.

Öyküde canavar Labbu'nun fiziksel özellikleri de belirtilmiştir. Ayaklarıyla yirmi millik sıçrayışlar yapabilen Labbu'nun uzunluğu elli mil, kalınlığı bir mil, ağzı altı arşın, dili on iki arşın, kulaklarının çevresi de on iki arşın idi. Balık, deniz ürünleri, yaban eşeği ve insan yiyebilen canavar Labbu, altmış arşın uzaktan diliyle kuşları yakalayabiliyordu. Kuyruğu da olan canavar Labbu, dokuz arşın derinliğindeki suyun içinde dolaşabiliyordu.

Nihayetinde canavarın öldürülmesi gerektiği kararına varan tanrılar, öldürme görevini ikinci dereceden bir tanrı olan Tişpak'a verdiler. Tanrılar, Tişpak'a, Labbu'yu öldürebilmesi için boynunda taşıdığı silindir mührün canavara fırlatılması gerektiğini de öğütlediler. Tanrıların buyurduğunu aynen yerine getiren Tişpak, kendi boynunda taşımakta olduğu silindir mührü firlatıp canavara doğru atınca, bir su ejderhası olan Labbu ölür. Ölen canavar Labbu'nun kanı ise tam üç y1l, üç ay ve bir gün (yani bin günden fazla bir zaman dilimi içinde) akmış ve ancak bu şekilde tükenmiştir.

Öyküde, kamu düzenini bozan, huzursuzluk çıkaran ve kaosun nedeni olan "Labbu" adlı canavardır. Labbu, toplumun huzurunu tamamen yok etmiştir. Sümer mitlerinde ilk kez adı belirtilerek ifade edilen canavar olan Labbu, aynı zamanda suda yaşar; yani Labbu bir deniz canavarıdır. Fiziksel özelliklerinin de vurgulandığı öyküde Labbu ağırlıklı olarak deniz ürünleriyle besleniyor olsa da, gerektiğinde insan ya da yaban eşeği de yiyebilmektedir; dolayısıyla insanların ölümüne de sebep olabilecek bir yaratık olan Labbu, çok korkunç bir canavardır. Nihayetinde emir komuta zinciri işler ve hiyerarşik olarak üstte bulunan tanrılar, ikinci sınıf bir tanrı olan Tişpak'a, Labbu'yu öldürme emri verirler; Tişpak da gereğini yerine getirir. Labbu adlı canavarın öldürülmesinde Tişpak kılıç kullanmaz; "büyü” yoluyla canavarı haklar. Böylece kamu düzeni bir başka söyleyişle toplumsal huzur da sağlanmış olur. Toplumun huzurunu sağlayan ve kaosu sonlandıran ise yine bir tanrı olur. Canavar Labbu'nun öldürülmesinin meşruiyeti ise kamu düzeninin sağlanması amaciyla açıklanır. Öyküde, tanrılara güvenilmesi gerektiği, tanrıların "büyü” yolunu da kullanabilecekleri, tanrıların gücünün her şeye yetebileceği ve tanrıların gerektiğinde kamu düzenini sağlayacakları vurgusu dikkat çekmektedir. Yani, her halükarda "kötülük", yine tanrılar tarafindan ortadan kaldırılmakta ve toplumsal yarar gerçekleştirilmiş olmaktadır. 


\subsection{Babillerde Mitolojik Canavar Yaratık Olgusu}

Canavar yaratık ve canavar yaratık öldürme öykülerine, Sümerlerden sonra Babillerde ${ }^{11}$ de rastlanılabilmektedir. Bu yazıda "Babillerde canavar yaratık olgusu" başlığı altında, önce Babiller hakkında kısa bilgi verilecek, akabinde de Babillerdeki canavar öyküleri analiz edilmeye çalışılacaktır.

Sami halkının (Akadlar, Asurlar ve Babiller) bir bölümü olan Babiller, M.Ö. iki binlerde Babil adlı yerleşim yerinde yaşamışlardır. Orijininde Babil, bir Sümer şehir devletidir. Bir dönem, İran'ın yüksek bölgelerinden başlayarak tüm orta doğuyu kaplayan ve doğu Akdeniz ülkelerine kadar uzanan bir toprak parçasına siyasal açıdan egemen olmuş, uzun bir süre bu bölgeleri kültürel açıdan biçimlendirmiş olan Babil, coğrafi açıdan Mezopotamya'nın güneyinde yer almaktadır. Günümüzde bir Irak kenti olan Samarra'nın güneyinde yer alan Babil, bir yerleşim yeri olarak M.Ö. iki binlerde ve öncesinde su, balçık ve kamışla kaplıydı ve ileri derecede kereste ve maden ihtiyacı duyulan bir yerleşim yeriydi.

M.Ö. 1792 yılı öncesinde (yani 6. kral Hammurabi tahta çıkana kadar) kendi dar coğrafi çerçevesinde bir güç olarak kalmış olan Babil, altıncı kral Hammurabi ile güçlü bir devlet olmuş; M.Ö. 539'da da Persler tarafindan yıkılmıştır. Fakat toplum olarak Babiller M.Ö. 160'lı yıllara kadar varlıklarını sürdürmüşlerdir. Eski Ahit üzerindeki etkileri küçümsenemeyecek boyutta olan Babiller, aslında Sümerlerden sonraki ilk büyük uygarlıklardan birisidir. Sümer dili olmayan ve bir çeşit Akad lehçesiyle konuşmuş olan Babiller, aslında önemli bir edebiyat da bırakmışlardır.

Özellikle büyü, astroloji, falcılık, astronomi ve diğer kehanet tekniklerinin yaygın olarak görüldüğü bir yerleşim yeri olan Babil, Kaldeliler olarak bilinen "Babil rahiplerinin yurdu" olarak da anılmaktadır. Tanrılarını insan biçiminde tasvir etmiş olan Babiller, çok tanrı inancını benimsemişlerdir. Eski Sümer tanrıları, Babiller tarafindan Sami isimler verilerek korunmuştur. Sümer mitleri, Babillerin önceliklerini yansıtacak şekilde, Babillere özgü olarak değiştirilmiş; Babil mitleri, Kitab-1 Mukaddes anlatılarının doğuşunu kuvvetle etkilemiştir. M.Ö. 950-400 arasında oluşturulmuş ve Kitab-1 Mukaddes'in bir bölümü olan Tevrat'ın ${ }^{12}$ içerdiği mitoloji, Yahveh tarafından seçilmiş olan halkın yani İsraillilerin, vaat edilmiş toprakları fethedebilmesini haklı kılmaya yarayan içerik ile de donatılmıştır. Bir Mezopotamya toplumu olarak Babillerde de, aynen Sümer mitolojisinde olduğu gibi ve hatta yer yer Sümer'den esinlenmeler ile birlikte canavar ve canavar öldürme motifini izleyebilmekteyiz. Az çok metni elde olan üç Babil efsanesinde canavar öldürme öyküsü bulunmaktadır. Şimdi, sözü edilen bu canavar öykülerini incelemeye geçebiliriz.

\footnotetext{
${ }^{11}$ Babiller hakkında ayrıntılı bilgi için bkz., Jursa, 2017: 7-8, 12-13, 23-24, 47, 49, 51, 99-100, 106 ve 149; Bottero ve Kramer, 2017: 11-13; Büyük Larousse, 1993: 1165-1166; Erdem, 1991: 392-395.

${ }^{12}$ Tevrat, Kuranı Kerim'de Yahudilerin kutsal kitabına verilen addır. Yahudi geleneğinde Tevrat "öğreti, doktrin, kılavuz, teori, hüküm, kanun, din” gibi anlamlar taşımaktadır. Bu kelime yani Tevrat kelimesi, Hz. Musa'ya verilen kitabın ismi olarak kullanıldığı gibi, Eski Ahit ve Yahudi din alimlerine ait bütün eserler için de kullanılmaktadır. Yahudi geleneğine göre bu külliyat Hz. Musa'ya Sina'da vahye dilmiş ve öğretilmiştir. Bazı Yahudi kaynaklarına göre Tevrat, dünyanın yaratılışından önce yaratılan yedi şeyden biridir. Tevrat dünya yaratılmadan dokuz yüz yetmiş dört nesil önce yaratılmış, dünyanın ve insanın yaratılışında Tanrı'ya danışmanlık yapmıştır (Tevrat konusunda ayrıntılı bilgi için bkz., Adam, 2012: 40-45).
} 


\subsubsection{Kahraman Gılgamış ve Canavar Humbaba}

Gılgamış destanı ilkin M.Ö. 1800'lerde, sonra M.Ö. 1600'lerde ve nihayet M.Ö. 1250'li yıllarda yeniden yazılan ve en az üç farklı şekli olan bir destandır ${ }^{13}$. İnsanoğlunun ilk yazınsal ürünü, ilk başyapıtı (Gılgamış Destanı, 2016: V; Şenel, 2006: 429) olan Gılgamıș Destanının orijini aslında Sümerlere dayanır (Roberts, 2011: 60) ve Gılgamıș destanının tamamının 2900 satır olduğu tahmin edilmektedir. Kahraman Gılgamış, Gılgamış'ın yoldaşı Enkidu ve canavar yaratık Humbaba (Huvava) olmak üzere, Gılgamış destanının üç temel karakteri bulunmaktadır.

Kelime anlamı "her şeyi bilen ve gören" olan Gılgamış yarı efsanevi bir kişidir. Annesi Ninsun adındaki tanrıça; babası ise şeytan (Lilla) olan Gılgamış, Uruk kentinin kralıdır (Gılgamış Destanı, 2016: XVIII). En geç M.Ö. 2700 yıllarında yaşamış olduğu tahmin edilen Gılgamış'ın, Uruk'ta hüküm sürmüş bir gerçek kişi (Roberts, 2011: 60; Şenel, 2006: 419-420; Çı̆̆ , 2017c: 13, 81) olduğu iddiasına da rastlayabiliyoruz.

Mit üreticileri tarafından Gılgamış'ın hem arkadaşı, hem de yoldaşı rolü oynatılan Enkidu ise hayvanlar arasında büyümüş olan insanımsı bir yaratıktır. Uruk'lu bir kadın (bir yosma) tarafından erkeklik içgüdüsü uyandırılarak kente götürülen ve uygar yaşama alıștırılan Enkidu, nihayetinde Gılgamış'la arkadaş olur (Gılgamış Destanı, 2016: XXIV). Enkidu, kelime olarak "kırların adamı" anlamına gelmektedir.

Gılgamış destanındaki "canavar yaratık” ise bu sefer karşımıza Humbaba (Huvava) adlandırmasıyla çıkmaktadır. Yarı insan, yarı tanrı, bir dev, bir canavar olan Humbaba, Gılgamış destanın bir anlatısına göre Gılgamış'ın arkadaşı Enkidu tarafından kafası kesilerek öldürülmüştür. Bahsi geçen Destanın başka bir anlatısına göre ise Humbaba'yı öldüren kişi Gılgamış olmuştur.

Gılgamış destanında, destanın canavar yaratığı olan Humbaba'nın fiziksel özellikleri de belirtilmektedir. Gücüne güç yetmeyen Humbaba, uyku nedir bilmez. Gücünü firtına tanrısından almış olan Humbaba'nın görüntüsü çok korkunçtur. Ağzı ateşe, soluğu ölüme, bağırması ise tufan gümbürtüsüne benzeyen Humbaba, aynı zamanda da tanrı soyundandır. Sözü edilen sebepten dolayı insan gözünün dayanamayacağı bir 1şık saçan Humbaba, aslında ölümsüzlük ülkesindeki canavardır (ejderhadır). Kükrediği zaman yeryüzünü ve gökyüzünü inleten Humbaba'nın dişleri ejderha dişi; yüzü ise aslan yüzüdür.

Gılgamış destanının öyküsü (Campbell, 2015c: 24, 97; Leeming, 2017: 39-42; Gılgamış Destanı, 2016: XXIV-XXV, 1-117; Çı̆g, 2017c: 56-57 ve 77) kahraman Gılgamış'ın Uruk kentinin kralı olmasıyla başlar. Uruk kentinin kralı olan Gılgamış acımasız ve güçlü bir yöneticidir. Bu yüzden tanrıça Aruru, Gılgamış'la başa çıkabilmesi için kilden bir adam (Enkidu) yoğurur. Hayvanlar arasında büyüyen Enkidu, bir yosma tarafindan uygarlaştırılır ve kente götürülür. Acımasız ve güçlü bir lider olan Gılgamış'la kapışan Enkidu Gılgamış'ı yenemez; ve fakat akabinde de arkadaş olurlar. Gılgamış, sedir ormanlarına gitmek, ormanın bekçisi olan dev canavar Humbaba'yı öldürmek ve akabinde de Uruk kentine kereste getirmek

\footnotetext{
${ }^{13}$ G1lgamış ve canavar Humbaba öyküsü konusunda bkz., Çığ, 2017c: 14, 28-29, 80 ve 82.
} 
istemektedir. Anılan amacın gerçekleştirilmesi bağlamında iki arkadaş, Humbaba adlı canavarı öldürmek için silah yaptırıp yola çıkarlar. Uzun bir yolculuktan sonra ormanın eteklerine gelirler. Nihayetinde canavar Humbaba'yı öldürürler ve gerekli ağaçları kesip, Fırat nehri üzerinden kente taşımaya hazırlanırlar. Yani Gılgamış, yabanıl arkadaşı Enkidu ile birlikte "tanrı Enlil'in Amanos yöresindeki sedir ormanlarına gözcü olarak koyduğu Humbaba" adlı korkunç canavarı öldürmüştür.

Gılgamış ve Enkidu Uruk'a döndüklerinde tanrıça İştar Gılgamış’a aşık olur ve kendisinin kocası olmasını ister. Fakat tanrıça İştar'ın teklifi Gılgamış tarafından reddedilir. Teklifinin reddedildiğine çok kızan tanrıça İştar, gök boğasını Gılgamış'ın üzerine salar; fakat iki arkadaş boğayı öldürürler. Tanrılar, hem Humbaba'nın, hem de gök boğasının öldürülmesinde dahli olduğu gerekçesiyle, sırf cezalandırmak amacıyla, Gılgamış'ın can yoldaşı Enkidu'yu ölüme mahkum ederler. Nihayetinde Enkidu hastalanır ve ölür. Yoldaşının öldügüne şahit olan Gılgamış da "ölüm korkusuna" kapılır ve bunun üzerine ölümsüz yaşamı aramak üzere yola çıkar. Gılgamış, ölümsüz yaşamın sırrının tanrılar tarafından tek kişiye (Utnapiştim'e) verildiğini, ölümsüzlük sırrının da esasında "denizin dibindeki dikenli bir bitkide" olduğunu öğrenir. Dilmun'a (yani Utnapiştim'in ülkesine, bir başka söyleyişle mitolojideki ölümsüzlük ülkesine) giden Gılgamış, denizin dibindeki dikenli otu alır ve fakat dönüş yolunda, yıkanmak amaciyla serin suyla dolu bir çukura girdiğinde, bitkiyi "yılana" kaptırır. Bitkinin kokusunu alan "yılan”, deliğinden çıkıp bitkiyi almış ve yuvasına geri dönerken de derisini değiştirmiştir. Kil tabletlerden elimize ulaşmış olan öykü, bu şekilde sona erer.

Babil adlı yerleşim yerinde, öykünün geçtiği dönemde ileri derecede kereste ihtiyacı vardı. Öyküde, kahraman Gılgamış, kereste ihtiyacı yüzünden anılan ihtiyacın giderilebilmesi kaygısıyla ormana gidip, canavar Humbaba'yı öldürmüştür; çünkü canavar Humbaba ormanın bekçisidir ve insanların kereste ihtiyaçlarını gidermesini engellemektedir. Öyküde böyle bir konuya yer verilmiş olması, aşırı derecede kereste yoksunluğu çeken topluma, ümit aşılanması amacıyla yapılmış olmalıdır. Böylece toplum, ihtiyacının giderileceğini, sorununun çözüleceğini düşünecek ve düşünsel düzlemde rahatlayacaktır. Humbaba adlı canavarın öldürülmesi ise aslında kamu yararının gerektirdiği bir teşebbüs olarak açığa çıkmaktadır. Yani, toplumun ihtiyaçlarının giderilmesini engelleyen canavar Humbaba, aslında düzeni bozmakta ve kaos çıkarmaktadır. Toplumsal çıkarın gerçekleştirilmesi kaygısıyla canavarın öldürülmesi de, kamu yararı saikıyla meşrulaştırılmış olmaktadır. Fakat sorun, tanrılar tarafından değil, yönetici-kral tarafından çözümlenir ve tanrılar arka plana atılır. Öyküde, ikinci olarak, toplum, kaçınılmaz bir hakikat ile yüzleştirilmekte ve bu hakikate de alıştırılmaktadır. Nedir bu kaçınılmaz gerçek? Tek kelimeyle "ölüm”dür. Kahraman Gılgamış bile ölümsüzlüğe çare bulamayıp ölüyorsa, demek ki, toplumun geri kalan kısmının da ölümü kaçınılmaz bir sondur. Dolayısıyla, ölüm hakikati ekseninde de, topluma yine moral aşılanmış olmaktadır.

\subsubsection{Kahraman Gılgamış ve Canavar Yılan}

Yukarıda "kahraman Gılgamış ve canavar Humbaba" başlığıyla öyküsü anlatılan Gılgamış destanının içinde, ikinci bir anlatı daha bulunmaktadır. Yani bir üst başlıkta üzerinde durulan Gılgamış destanı hem kendi öyküsünü, hem de ikinci bir efsaneyi 
bünyesinde barındıran metindir. Gılgamış destanının içinde yer verilen ikinci öykü (Gılgamış Destanı, 2016: 119-120), "Fırat nehrinin kıyısında küçük bir söğüt ağacının olduğuna" işaret ederek başlamaktadır. Fakat esasında bir tanrı olan Güney Rüzgarı sözü edilen bu söğüt ağacını kökünden söküp attı. Bunun üzerine tanrıça İnanna ağacı kendi bahçesine dikti. Tanrıça İnanna, ilerleyen zamanlarda söğüt ağacının kerestesinden bir taht, bir de yatak yaptırmayı düşünmektedir. Ne ki, tanrıça İnanna amacını gerçekleştiremez; çünkü anılan sögüt ağacının köküne korkunç bir "yılan"; tepesine bir kartal, ortasına da bir şeytan yerleşir. Tanrıça İnanna'nın yardımına koşan kahraman Gılgamış ise söğüt ağacını kesmiş, “yılanı” öldürmüş, kartalı dağa, şeytanı ise çöle sürmüştür.

Tanrıça İnanna, Gılgamış'ın bu iyiliğine karşılık, söz konusu söğüt ağacından, Sümer ve Babil mitolojisinde iktidar simgesi ve büyü aracı olan davul ve tokmak yapması için kurtarıcısına izin verir. Gılgamıș da, söğüt ağacının gövdesinden kendisine davul ve davul tokmağı yapar. Fakat Gılgamış, "genç kızların yakınmaları üzerine" davul ve tokmağı cehenneme düşürür. Bunun üzerine Gılgamış'ın yoldaşı Enkidu, Gılgamış'a yardım olsun diye yeraltına iner ve davul ve tokmağı geri getirmek ister. Fakat öykünün devamı yoktur; çünkü destan, esas olarak yukarıda bahsi geçen Gılgamış ve Humbaba macerasına özgü olarak kurgulanmıştır.

"Kahraman Gılgamış ve canavar yılan" adlı öyküde karşımızda olan dönemsel hakikat, Babil kentinin kereste ihtiyacına yapılan vurgudur. Kahramanımız Gılgamış, Babil'in kereste ihtiyacının giderilmesi için yine sahnededir ve rolünü bihakkın yerine getirir; öncelikle canavar yılanı öldürür, sonra kartalı ve şeytanı da kaçırır. Böylece kereste ihtiyacının giderilmesinin önündeki engeller de ortadan kaldırılmış olur. Fakat bu kez kereste ihtiyacının karşılanmasının önündeki engeller tek değil üç adet (yılan, kartal ve şeytan) olarak kurgulanmıştır. Yani, kamu düzenini bozan, kaos oluşturan veya kamu yararının gerçekleştirilmesine engel olan sorunlar, yine bir süper kahraman tarafından, toplum yararına olarak, çözümlenir ve toplumun huzurunun önündeki kötülük yok edilir; fakat sorun çözücü tanrılar değil, yönetici-kraldır.

\subsubsection{Tanrı Marduk ve Canavar Tiamat}

Tanrı Marduk ve tanrıça canavar Tiamat arasındaki öykü, Babil Yaratılış Destanı (Enuma Eliş) adıyla anılan bir efsanede geçmektedir. Babil Yaratılış Destanı (Enuma Eliş $^{14}$, Babillerin baş tanrıları olan Marduk'u yüceltmek için, eski Sümer kavram ve metinlerinden yararlanarak yazdıkları kapsayıcı bir dini metindir. Babil Yaratılış Destanı, çivi yazılı 159 tablette bulunmaktadır. Tanrı Marduk heykelinin huzurunda her yıl Nisan ayında tapınakta terennüm edilen bir metin olan Babil yaratılış Destanı (Enuma Eliş), yedi bölüme ayrılır ve terennüm edilebilmesi için metin içinde sıkça tekrarlara yer verir. Sözü edilen bu durum da, Enuma Eliş metnine estetik açıdan ahenk katmaktadır. Kelime olarak Enuma Eliş "başlangıçta göklerde" veya "henüz yukarıya" anlamlarına gelmekte ve Babil Yaratılış Destanı olarak anılmaktadır. M.Ö.

\footnotetext{
${ }^{14}$ Babil Yaratılış Destan1, 2016: VII-XIII, 3-9, 13-19, 24, 31-36, 41 ve 47-53; Şenel, s. 414-417. Leeming'e göre Enuma Eliş (Babil Yaratılış) Destanı, "dişinin güçlü ve doğurgan olduğu dönemin sonunu, kent merkezli ataerkil yeni düzenin kuruluşunu" anlatmaktadır. Bu konuda bkz., Leeming, 2017: 37-38; Bottero ve Kramer, 2017: 692-748.
} 
2. binyılda yazıya geçirildiği düşünülen Babil Yaratılış Destanının, M.Ö. 3. binyılda derlenip tabletlere geçirildiğini ve aslında Sümer yaratılış mitosu (Şenel, 2006: 414415) olduğunu da dikkatlere sunalım. Enuma Eliş (Babil Yaratılış Destanı) adıyla anılan söz konusu bu hikaye, bazı değişiklikler ile Babil İmparatorluğu sonrası kurulan Asur egemenliğinde Asur yaratılış mitine, sonra da Yahudi kültürüne geçmiştir.

Enuma Eliş (Babil Yaratılış Destanı), evrenin yaratılışını anlatmakla başlar. Dünya yokken, yani yeryüzü ve gökyüzü yokken tatlı sular (Apsu) ve tuzlu sular (Tiamat) vardı. Apsu, tanrıların ileri geleni ve babasıdır. Tiamat ise bütün tanrıları doğuran bir tanrıçadır. Birbirine aşık bu iki kozmik varlığın birbirine karışmasının ardından suların içinde (aslında birer su canavarları olan (Bottero ve Kramer, 2017: 752) tanrı Lahmu ve tanrıça Lahamu yaratılır. Sonra Ansar ve Kisar yaratılır; fakat Ansar ve Kisar önceki tanrılardan daha güçlü olurlar. Akabinde de Ansar ve Kisar'ın oğlu Anu yaratıldı. Bir araya gelip konuşan genç tanrıların çıkardığı gürültü, tanrıça Tiamat'ın canını sıktı. Sözü edilen gürültüden Tiamat'ın kocası olan Apsu da yakınmaktaydı. Bunun üzerine Apsu, durumdan Tiamat'ı haberdar etti. Apsu, karısı Tiamat'a, "uyumak istiyoruz, fakat genç tanrılardan bazılarının yaptığı gürültü huzurumuzu kaçırıyor" dedi. Apsu, karısı Tiamat'a, "gürültü yapan tanrıları dağıtmak istiyorum" şeklinde bir serzenişte de bulundu. Fakat tanrıça Tiamat, kocası Apsu'ya kızdı ve "biz, yarattıklarımızı neden yok edelim" dedi. Fakat Apsu'nun veziri Mummu, "ancak gürültü yapan genç tanrıları dağıtırsan geceleri uyuyabilirsin" diye Apsu'yu kışkırttı. Apsu'nun, kendilerini dağıtmak istediğini öğrenen genç tanrılar bunun üzerine az da olsa kendilerine çeki düzen verdiler. Fakat gürültü yapan genç tanrıların zekileri olan Ea, şikayetinden dolayı Apsu'yu büyüledi ve onu önce uyuttu sonra da öldürdü.

Ea'nın eşi Damkina idi. Sonra Ea ve Damkina'nın oğlu olan Marduk doğdu. Marduk, Ea'nın oğludur. Dört gözü ve dört kulağı olan Marduk'un ağzından alevler çıkardı. Dört kulağ1 ve dört gözü de iri olan Marduk'un gözleri her şeyi görürdü. Görünüşü heybetli olan Marduk'un kolları ve ayakları da uzundu. Yani Marduk, doğuştan üstün doğmuştu. Rüzgar estiren, toz-toprak kaldıran Marduk, bu eylemlerinden dolay1 tanrıça Tiamat'ın huzurunu kaçırıyordu. Bazı tanrılar da, "rüzgar estirmesinden dolayı uyuyamıyoruz, uykusuzluktan da gözlerimiz bozuluyor" diyerek, Marduk'u, Tiamat'a şikayet ettiler ve Marduk'un öldürülmesini, böylece sorunlarının çözülmesini talep ettiler. Öteki bazı tanrılar da, kocası Apsu'nun öldürülmesinden dolayı, kocasının öcünü alsın diye, tanrıça Tiamat'ı Ea'ya saldırması için kışkırttılar. Nihayetinde ikna olan tanrıça Tiamat da, hem kocasının öldürülmesinin öcünü almak, hem de Marduk'u cezalandırmak için diğer tanrılarla aynı fikri paylaşmaya başladı. Tiamat, Ea'dan öç almak istiyordu; çünkü Ea, Tiamat'ın kocasını öldürmüştü. Tiamat, Marduk'u da cezalandırmak istiyordu; çünkü rüzgar estirip toz kaldırıyordu.

Tanrıça Tiamat ile "Ea ve oğlu Marduk" arasındaki savaşta kullanılmak üzere tanrılardan birisi silah getirdi ve bir sürü canavar (ejderha) doğurdu. Ek olarak, Tiamat da çok sayıda yırtıcı Leviathan (dev deniz canavarları olan ejderhaları) doğurdu (Bottero ve Kramer, 2017: 699, 701, 709, 712). Dişleri keskin olan canavarların içini kan yerine zehirle dolduran Tiamat, canavarları korkutucu 1şıklarla 
sardı ve onları tanrılara benzetti. Ana tanrıça Tiamat'ın doğurduğu canavarları gören korkudan bayılabilir, ayağa kalkamaz ve güçten düşerdi. Tanrıça Tiamat; boynuzlu yılanı, yılan ejderhayı ve Lahamu'yu (tüylü canavarı) yarattı. Aslan başlı adamlar, balık adamlar ve akrep adamlar da yaratan tanrıça Tiamat, güçlü bir canavar ordusu kurdu ve yeni sevgilisi Kingu'yu da kral ilan etti. "Ağzınızdan ateş püskürtün” diye başlayan Tiamat, "zehriniz, güçlünün gücünü yok etsin" diye de ekledi. Kocası ve sevgilisi olan Kingu'yu kutsayan Tiamat, "kaderler tabletini”(Babil Yaratılıș Destanı, 1993: 9) de (kaderler tabletini elinde tutan tanrının, söylediği her şey geçerli olurmuş) Kingu'ya verdi.

Tiamat'ın kocası Apsu'yu öldürdüğünden dolayı başına gelecekleri anlayan Ea korkmaya başladı. Ea'nın babası ise korkmamasını, cesur olmasını ve Tiamat'a saldırmasını istedi. Fakat korkan ve geri dönen Ea, oğlu Marduk'u çağırdı. Ea, Marduk'a, Tiamat'a saldırması gerektiğini söyledi. Bunun üzerine Marduk da, kendisinin Tiamat'a saldıracağını, ötekilerin korkmamaları gerektiğini beyan etti. Fakat kendisine önerileni, Marduk, şartlı kabul etmişti. Tiamat'1 öldürünce en üstün tanrı olarak kabul edilmesi gerektiğini dillendiren Marduk'un teklifi, öteki tanrılar tarafından kabul edildi. Değişik bir ifadeyle belirtirsek, babası Ea'nın cesaretlendirmesiyle Marduk, Tiamat ve Kingu ile savaşmaya gönüllü olur. Karşıllğında ise bütün evrenin hâkimiyetini isteyen Marduk'un talebi öteki tanrılar tarafindan kabul görür.

Mücadelenin başlamasıyla Marduk'un attığı ok, Tiamatın karnını deler ve Tiamat ölür. Tiamat'ın ölmesi üzerine canavarlardan oluşturduğu ordusu da dağılır. Tiamat'ın on bir canavarını esir alan Marduk, Tiamat'ın kocası Kingu'da bulunan "kaderler tableti"ni ele geçirir. Nihayetinde, Marduk'un yardımcılarından Bel, topuzu ile Tiamat'ın kafasını parçaladı ve damarlarını kesti. Bir canavar (ejderha) olarak tanımlanan Tiamat'ın parçalarından yararlanarak, Marduk, gökyüzünü, yeryüzünü, Firat ve Dicle nehirlerini yarattı. Frrat ve Dicle nehirleri, Marduk tarafindan Tiamat'ın iki gözünden akıtılmıștır. Sonrasında ise Babil kenti kurulur ve tanrılar Marduk'u sonsuza dek kral kabul ederler. Marduk, babası Ea'ya, "kanları bir araya toplayacağım, kemikleri bir araya toplayacağım, sonra o kalabalığı adı insan olan bir varlık şeklinde ayağa kaldıracağım" der. "Böylece tanrılar dinlenmeye zaman bulabilecek ve tanrıların işleri o insanların üzerinde kalacak" diye de ekler Marduk.

Fakat babası Ea'nın, Marduk'a 'tanrıların arasından bir kardeş bize teslim edilsin, bu tanrı öldürülsün ve insanlar ondan yaratılsın" şeklinde farklı bir önerisi olur. Bunun üzerine Marduk büyük tanrıları toplar ve "bana gerçeği söyleyin, savaşı kim başlattı, Tiamat'ı isyana kim teșvik etti" der. Tanrıların Marduk'a yanıtı "savașı başlatanın Kingu olduğu" şeklindedir. Tiamat'1 Kingu'nun kışkırttığını ve savaşı Kingu'nun başlattığını öğrenen Marduk, öldürülen ve damarları kesilen Kingu'nun kanından insanı yarattı. Nihayetinde insanlar, Enuma Eliş (Babil Yaratılış) destanına göre, isyan eden Kingu'nun kanından yaratılmışlardır. İnsan, tanrıların iş yükünü üstlendi ve böylece tanrılar özgür oldular. İnsanlar yaratıldıktan sonra tanrıların işleri de insanlara kaldı. Yarattığı insanlara tanrıların işlerini yükleyen Marduk, tanrıların dinlenebilmesi için onlara ortam hazırlamış oldu. Kendilerine dinlenebilecek zaman tanındığını gören tanrılar, Marduk'a, "bize özgürlügümüzü verdin, senin için şanlı bir 
tapınak yapalım, senin makamın bizim evimiz olsun, biz de orada dinlenelim" dediler. Marduk, bunun üzerine tanrılara, "Babil'i inşa edin, sizin işiniz odur, Babil sizin yurdunuzdur, burada neşeyle oturun" diye yanıt verdi.

Enuma Eliş (Babil Yaratılış Destanı) anlatısına göre yaratmak, yok etmek, affetmek ve cezalandırmak artık Marduk'un emriyle olacaktır. Tanrıların, Marduk'u kral ilan etmesinin ardından Marduk, bütün evreni yeniden yaratmış ve günümüz dünyası oluşmuştur. Marduk'un elli adını zikreden tanrılar, ardından Marduk'a Ea adını da vermişlerdir. Babil Yaratılış Destanı insanlar arasında okunması ve bilinmesi talimatıyla da sona erer.

“Tanrı Marduk ve canavar Tiamat” adıyla adlı öyküde, ilkin, genç tanrıların yani çocukların yaramazlığını, babanın onları cezalandırmak istediğini fakat annenin (belki de anne şefkatiyle), buna karşı çıktığını görüyoruz. Öte yandan sözü edilen öyküde, ikincil olarak, öldürülen bir kocanın olduğunu fakat öldürülen bu kocanın öcünün karısı tarafından alınmadığını da gözlemleyebiliyoruz. Kendiliğinden harekete geçerek kocasının öcünü almak için bir şey yapmayan tanrıça Tiamat, "genç tanrılar"’n onu uyarması ve kışkırtması üzerine öldürülen kocasının öcünü almak için harekete geçmiştir. Üçüncü olarak, tanrıça Tiamat'ın kocasını öldüren katilin (Ea'nın) oğlunun (yani Marduk'un) şımarıklığı da öyküye eklenmiştir. Öyküde canavar olarak betimlenen Tiamat, kadındır ve annedir fakat üzerine düşen sorumluluğu (yani kocasının öcünü almak bağlamında) yerine getirmemektedir. Bu yönüyle Tiamat, kaos ve kötülük sembolü olarak toplumun önünde durmaktadır. Doğaldır ki, kamu yararı bağlamında anılan sorunun çözümlenmesi, kamu düzeninin yeniden sağlanması ve topluma iyi örnek olunması gerekmektedir; görev tanrı Marduk'a havale edilir ve asayiş sorunu Tiamat'ın öldürülmesi suretiyle giderilir. Bir başka söyleyişle, yaramazlık eden genç tanrılar kamu düzenini bozuyor ve huzursuzluk çıkarıyorlardı. Tanrıça Tiamat'ın huzursuzluğu gidermesi istenince, Tiamat kendinden bekleneni yerine getirmez, öç almaz, insanları cezalandırmaz, yani adaleti yerine getirmez; çünkü kadındır. Bu bağlamda öyküde, bir ölçüde de olsa, kadının toplumsal rolünün küçümsendiğinin ve erkek egemen bir dünyaya geçişin gerekliliğinin vurgulandiğı da söylenebilecektir. Üzerinde durulması gereken diğer bir konu da, bu makalenin esas inceleme konusu bağlamında, öyküde mitolojik olarak ilk defa Leviathan ibaresiyle karşılaşıyor oluşumuzdur. Mitolojide Leviathan ibaresi, ilk kez Babil Yaratılış Destanı'nda kullanılmıştır; akabinde ise Kitab-1 Mukaddes'in Leviathan'ı kullandığını görürüz. Leviathan, bahsi geçen bu öyküde tanrıça Tiamat tarafından doğurulan (Marduk ile savaşması için doğurulan) pek çok canavardan birisidir ve de kötülük ve kaos sembolüdürler. Tiamat tarafindan çok sayıda olarak doğurulan leviathanlar, birer "deniz canavarı" olarak betimlenmektedirler.

\section{Genel Kamu Hukukunda Canavar Yaratık Olgusu: Kitab-ı Mukaddes'ten Thomas Hobbes'a}

İşbu makalenin yazılmasına neden olan temel sorunsallardan birisi, aslında Leviathan ibaresi (yeri gelmişken hemen hatırlatalım, ikincisi ise Behemot terimidir) ve bu kelimenin mitolojideki ve Thomas Hobbes'taki anlamının belirginleştirilmesi olmuştur. Bir başka söyleyişle, Babil Yaratılış efsanesinde ve Kitab-1 Mukaddes’te dillendirilen bir canavar olan Leviathan terimini, ünlü İngiliz siyaset filozofu ve 
devlet teorisyeni Hobbes, "monarşik devleti savunduğu" bir eseri için başlık olarak belirlerken hangi kaygıyla hareket etmiştir? Hobbes'un kendi özgün devlet teorisini içeren bir kitabın başlığı olarak, niçin Leviathan terimi esas alınmıştır? Monarşik devleti savunan bir tezi içeren kitabın başlığı niçin Leviathan olarak belirlenmiştir? Monarşik devlet ile Leviathan arasında nasıl bir bağlantı vardır? İşte anılan soruların yanıtının bulunması amacıyla yazımına girişilen bu makalede, artık bahsi geçen soruların yanıtını vermeye başlayabiliriz. Bu bağlamda ilkin canavar yaratık ile Leviathan bağlantısı kurulmalıdır.

\section{1. "Canavar Yaratık" ve Leviathan Bağlantısı}

Fenike mitolojisinde adı geçen ve daha çok Kitab-1 Mukaddes'ten tanınan bir canavar olan Leviathan'dan, Kitab-1 Mukaddes (Eski Ahit bölümü) değişik biçimlerde söz eder. Leviathan bazen Nil Irmağındaki timsahın kendisidir; bazen de Kitab-1 Mukaddes'in İşaya bölümündeki gibi paganlığın simgesidir (Büyük Larousse, 1993: 7454; Gürkan, 2010: 99-103; Şahin, 1993: 5-8; Sarıtoprak, 1993: 393-395). Bu Yazı bağlamında ise biz, Leviathan ifadesini ejderha, canavar, yılan ve benzerleri anlamında kullanıyor olacağız; çünkü ilk kez Babil Yaratılıș Destanında (Enuma Eliş), ikinci kez de Kitab-1 Mukaddes'te kullanılmış olan Leviathan terimi ile hangi canlı türünün kastedildiğini kelimenin tam manasıyla bilemiyoruz. Belki de Leviathan'ı, en azından bu yazı bağlamında, öncelikli olarak "canavar" ibaresiyle eş anlamlı saymalıyız; çünkü Leviathan adlı bir eserin yazarı da olan Hobbes, unutmayalım ki, doğduğu yerden hareketle doktrinde (Tuck, 2015: 57) "Malmesburry Canavarı" olarak anılmaktadır.

Özüne indirgendiğinde, Leviathan teriminin kökünün "levi” olduğunu söyleyebiliriz. Hz. Yakup ile Lea'nın üçüncü oğlu olan Levi (Campbell, 2015: 37; Büyük Larousse, 1993: 7454), aynı adlı bir İsrail kabilesinin atasıdır; ve aynı zamanda Kutsal Kitaplarda havari aziz Matta'nın öteki adıdır. Levi, Eski İsrail'de, geleneksel olarak tapınağın hizmetine bakan "Levi kabilesinin üyesi" anlamına da gelir. Küçük yerel tapınakların bırakılıp, dinin, Kudüs'te merkezileşmesiyle birlikte rahiplerle Leviler arasında bir ayrım ortaya çıkmıştır. Zamanla, Leviler, Yehova dininin alt düzeydeki rahipleri durumuna geldiler. Bunun üzerine rahiplik görevleri ise Harun soyundan gelenlerin tekeline girdi ve Levi kabilesi de, yalnızca din işleriyle görevli olan İsrail kabilelerinden birisi oldu. Levi kabilesinin üyelerinin kendilerine ait toprakları yoktur ve öbür kabileler, Levi kabilesinin gereksinimlerini karşılamak zorundadır.

Geldiğimiz bu noktada baş aşağı duran kavramı yani Leviathan ibaresini, artık ayakları üzerine dikebiliriz. Bir başka ifadeyle, Leviathan teriminin etimolojik kökenini ve anlamını netleştirebiliriz. Aslında terim olarak Leviathan "Levi kabilesine ait olan", "Levililerin malı olan", "Levililere özgü olan” yani "mülkiyeti Levililere ait olan" bir canavarı anlatmaktadır. Mitolojideki canavar yaratık, Levililer tarafından ve Levililer için Leviathan olarak anılmakta ve algılanmaktadır. Başka bir ifadeyle, her toplumun mitolojik olarak kendine özgü bir canavarının olması hakikati ve ihtiyacı, Levililerde, "Leviathan" ibaresi ile karşılanmaktadır. Canavar yaratığın Levi versiyonu Leviathan'dır; ve bahsi geçen terim, aynen, adıyla adlı, Kitab-1 Mukaddes'te de geçmektedir. 


\subsection{Kitab-ı Mukaddes'in Eski Ahit Bölümünün Canavarları: Leviathan, Behemot ve Rahav}

İlk kez Babil Yaratılış Destanı'nda ifadesini bulduğumuz Leviathan, sonrasında aynı adla Kitab-1 Mukaddes’te (Eski Ahit bölümünde) zikredilmiştir. Kitab-1 Mukaddes’te ise Leviathan bir canavar yaratık türü olarak tek değildir. Yeni ve farklı iki canavar yaratık türü olan Behemot ve Rahav da, Kitab-1 Mukaddes'te Leviathan'a ek olarak dillendirilmişlerdir.

Günümüzde uzmanlar Leviathan'ın esin kaynağının bir balina olduğunu varsaymakta iseler de, aslında Leviathan yüzyıllar boyunca şeytan ile de özdeşleştirilmiştir (Dell, 2014: 92). Öte yandan, Kitab-1 Mukaddes'e düşülen bir dipnotta Leviathan'ın hangi hayvan olduğunun bilinmediği, timsah ya da soyu tükenmiş bir hayvan olduğunun sanıldığı da belirtilmektedir (Kitab-1 Mukaddes, 2011: 569). Kitab-1 Mukaddes'te Leviathan ibaresinin kullanıldığı bağlamı incelediğimizde, Tanrı'nın, kendisinin ne kadar büyük ve güçlü olduğunu izah etmek için güçlü yaratıklardan Hz. Eyüp'e örnek verdiğine şahit olmaktayız. Tanrı, Hz. Eyüp'e "ben de Leviathan gibiyim" demek istiyor; yani, Tanrı, güçlü ve kudretli olduğunu vurgulamak istiyor. Bunun üzerine Hz. Eyüp de Tanrı'ya, "tamam şimdi gördüm seni” diye cevap veriyor. Burada bahsi geçen ve Kitab-1 Mukaddes'te "kaosu" temsil eden Leviathan gibi dehşet verici bazı yaratıkların (Dell,2014: 14, 20) yaratılış sebepleri ilk bakışta açık olmasa bile, tanrıların eseridirler. Sonraları ortaya atılan "Leviathan'ın aslında şeytan olabileceği" görüşü ise yaratıcı ile yaratan arasındaki ilişkinin ne kadar sıkıntılı olabileceğini açığa vurmaktadir.

"Yılana benzeyen bir deniz canavarı" olarak tasvir edilen Leviathan terimi, Kitab-1 Mukaddes’te Eyüp, Mezmurlar ve İşaya olmak üzere üç ayrı bölümde geçmektedir. Kitab-1 Mukaddes'te, sorularla, Leviathan'ın fiziksel özellikleri de ayrıntılı olarak bildirilmektedir. Kitab-1 Mukaddes'teki sözü edilen bu sorulardan hareketle, fakat makale formatına uygun bir şekilde sorular olarak değil de düz cümle olarak Leviathan'ın fiziksel özelliklerini (Kitab-1 Mukaddes, 2011: Eyüp: 41/1-34, 569; Mezmurlar: 74/14, 616; Mezmurlar: 104/24-26, 636; İşaya: 27/1, 738.) şöyle siralayabiliriz.

"Çengelle çekilemeyen, dili halatla bağlanamayan, burnuna sazdan ip takılamayan, kancayla çenesi delinemeyen Leviathan, kimseye yalvarıp yakarmaz ve de kimseyle tatlı tatlı konuşmaz. Ömür boyu kölelik yapacağına dair kimseyle antlaşma yapmayan Leviathan ile kuşla oynar gibi oynanamaz. Hizmetçiler eğlensin diye tasma takılamayan Leviathan'ın üzerine balıkçılar pazarlık edemez ve de tüccarlar onu aralarında bölemez. Leviathan'ın derisi zıpkınlarla, başı da mızrakla doldurulamaz. Hiç kimse elini Leviathan'ın üzerine koyamaz; eğer koyarsa, çıngar çıkar. Leviathan'1 kimse yakalayamaz; görünüşü bile insanın ödünü patlatır. Onu uyandıracak kadar yürekli adam yoktur. Leviathan'ın giysisinin önünü kimse açamaz. İki katlı zırhının delinemez olduğu Leviathan'ın dehşet verici dişleri karşısında ağzının kapılarını açmaya kimse yeltenemez. Leviathan'ın sırtındaki sıra sıra pullar, birbirine o kadar yakındır ki, aralarından hava bile geçmez. Hapşırması 1şık saçan Leviathan'ın gözleri şafak gibi parıldar; ağzından alevler fışkırır, kıvılcımlar saçılır. Kaynayan kazandan, yanan sazdan çıkan duman gibi burnundan duman tüten Leviathan'ın soluğu 
kömürleri tutuşturur, ağzından da alev çıkar. Çok güçlü bir boynu olan Leviathan'ın etinin katmerleri birbirine yapışmış ve sertleşmiştir. Göğsü değirmenin alt taşı gibi sert olan Leviathan ayağa kalktı mı güçlüler dehşete düşer, çıkardığı gürültüden ödleri patlar. Leviathan'ın üzerine gidildi mi, ona karșı ne kılıç, ne mızrak, ne cirit, ne de karg1 işler. Leviathan için demir, "saman" gibidir; tunç ise çürük odun gibidir. Okların bile kaçıramadığı Leviathan'a, sapan taşları da, topuzlar da, vınlayan pala da anız gibi gelir. Karnının altı keskin çömlek parçaları gibi olan Leviathan, bir düven gibi çamura uzanır. Derin suları, kaynayan kazan gibi fokurdatan Leviathan, denizi de merhem çömleği gibi karıştırır ve ardında parlak bir iz bırakır. Yeryüzünde bir eşi daha olmayan Leviathan korkusuz bir yaratıktır ve kendini büyük gören her varlığ aşağılar, gururlu her varlığın kralı da odur.

Birden fazla başı olan Leviathan Tanrı tarafindan yaratılmıştır ve uçsuz bucaksız denizler içinde oynaşır. Tanrı bir gün Leviathan'ı, o kaçan “yılanı”, o kıvrıla kıvrıla giden "yılanı" acımasız, kocaman, güçlü kılıcıyla cezalandıracak ve de denizdeki canavarları öldürecektir."

Kitab-1 Mukaddes'te yer alan ve az önce ifade edilen Leviathan tasviri incelendiğinde, bir yönüyle, Babil Yaratılış Destanı'nda tanrı Marduk'un öldürdüğü canavar Tiamat'tan bahsediliyor gibidir. Nasıl ki Babil Yaratılış Destanı'nda tanrı Marduk, canavar Tiamat'1 öldürdü; Kitab-1 Mukaddes'e göre, Tanrı da bir gün Leviathan'1 öldürecektir. Nihai tahlilde bakıldığında Leviathan, dünyada eşi benzeri olmayan yani "tek" olan bir yaratıktır ve Tanrı tarafindan yaratılmıștır. Gururlu varlıkların da kralı olan Leviathan üzerine, ticaret bağlamında, balıkçılar da pazarlık edemezler. Birden fazla başı (kaç adet olduğu belirtilmemiş), sırtında pulları, sağlam derisi ve güçlü dişleri olan Leviathan'ın, ağzından ateş, burnundan duman çıkar. Çok güçlü bir yaratık olan Leviathan'ın görüntüsü oldukça korkunçtur. Denizde (sularda) ve bataklıklarda yaşayan Leviathan'ın çamur üzerine uzandığı söz konusu olsa da, aslında, Leviathan, Kitab-1 Mukaddes'e göre bir “yılan”dır. Tanrı, bir gün, Leviathan'ı, güçlü kılıcıyla öldürecektir. Yani Leviathan'ın canı, Tanrı tarafından alınacak, sadece Tanrı tarafından alınabilecektir. Dolayısıyla Leviathan, sadece Tanrı tarafından öldürülebilir güçte olan bir canavar yaratıktır. Kaldı ki, Tanrı, Leviathan'ı öldürdükten sonra denizlerdeki öteki canavarları da yok edecektir.

Kitab-1 Mukaddes'te, Leviathan benzeri öteki iki canavar yaratıktan birisi de, Behemot olarak anılmaktadır. Kitab-1 Mukaddes'e düşülen bir dipnotta, Behemot'un hangi hayvan olduğunun kesin olarak bilinemediği; su aygırı, fil, timsah ya da soyu tükenmiş bir hayvan olduğunun sanıldığı ifade edilmektedir (Kitab-1 Mukaddes, 2011: 568). Kitab-1 Mukaddes'te sadece Hz. Eyüp kısmında dillendirilmiş olan Behemot'un sözü edilen bölümde fiziksel özellikleri ${ }^{15}$ de vurgulanmaktadır. Bu fiziksel özelliklerden hareketle Behemot'un, ot yiyen ve bataklıkta yaşayan güçlü kuvvetli bir yaratık olduğu sonucunu çıkartabilmekteyiz.

“Tanrı'nın, insanla birlikte yaratmış olduğu Behemot, sığır gibi ot yiyen, beli ve karın kasları güçlü olan bir yaratıktır. Kuyruğunu sedir ağacı gibi sallayabilen Behemot'un uyluk lifleri de sımsıkıdır. Kemikleri tunç borular, kaburgaları demir çubuklar gibi

\footnotetext{
${ }^{15}$ Behemot'un fiziksel özellikleri için bkz., Kitab-1 Mukaddes, Eyüp: 40/15-24, 568.
} 
olan Behemot, Tanrı'nın yapıtları arasında ilk sırayı alır ve ona sadece yaratıcısı kılıçla yaklaşabilir. Tepelerin bile hediye olarak ürünlerini kendisine getirmiş olduğu bir yaratık olan Behemot, hünnap çalıları altında, kamışlarla örtülü bir bataklıkta yatar. Hünnaplar, Behemot'u gölgelerinde saklar, vadideki kavaklar ise kuşatır. Şeria ırmağı boğazına dayansa bile, ırmak coşsa bile Behemot ürkmez; daima güvenlik içindedir. Gözleri açıkken kimse Behemot'u tutamaz ve kancayla burnunu delemez."

Nihai tahlilde bakıldığında Behemot bataklıkta yaşayan, ot ile beslenen ve kuyruğu olan güçlü bir yaratıktır. Tanrı tarafından yaratılmış olan Behemot, yine sadece Tanrı tarafından kılıçla öldürülebilecek olan bir canlı türüdür. Behemot, bir yönüyle, sanki ormanların bekçisi olan ve Gılgamış Destanı'nda adı geçen canavar Humbaba'yı da anımsatmaktadır.

Kitab-1 Mukaddes’te ifade edilmiş olan üçüncü canavar yaratık ise Rahav adıyla anılmaktadır. Kitab-1 Mukaddes'e düşülen bir dipnotta Rahav'ın, Kenan efsanelerinde geçen kaos ve kötülük güçlerini simgeleyen bir deniz canavarı olduğu (Kitab-1 Mukaddes, 2011: 542) belirtilmektedir. Kitab-1 Mukaddes'e göre, her ne kadar yardımcıları olsa da, yardımcıları ayağına kapanacak kadar güçlü bir yaratık olsa da, Rahav, Tanrı tarafından parçalanan, bedeni deşilen bir deniz canavarıdır (Kitab-1 Mukaddes, 2011: Eyüp: 9/13, 452; İşaya: 51/9, 767) ${ }^{16}$.

Nihai tahlilde bakıldığında Rahav da güçlü bir deniz canavarıdır. Fakat Tanrı'nın gücü daha fazla olduğu için Rahav'ı öldürmeye yetmiştir; çünkü Tanrı, Rahav'ın bedenini deşmiş ve Rahav'ı parçalara ayırmıştır.

Sonuçta, mukayeseli olarak bakarsak, Kitab-1 Mukaddes’te (Eski Ahit bölümünde) zikredilen her üç canavar da suda yaşamaktadır. Leviathan ve Rahav açıkça deniz canavarıdır; Behemot ise bataklıkta yaşar. Dolayısıyla anılan canavarlardan her üçü de "su canavarı" olarak nitelendirilebilirler; belki bir ölçüde Behemot, az da olsa kara canavarı özelliğini de bünyesinde barındırmaktadır. Kitab-1 Mukaddes'te Leviathan yılana, Behemot ise sığıra benzetilmektedir. Rahav'ın ise hangi canlı türüne benzediğine dair bir vurguya Kitab-1 Mukaddes'te yer verilmiş değildir. Behemot'un ve Rahav'ın "tek" olup olmadığını Kitab-1 Mukaddes'ten çıkaramıyoruz; fakat Leviathan "tek"tir ve bu durum açıkça Kitab-1 Mukaddes'te ifade edilmiştir. Behemot'un ve Rahav'ın kaç adet başının olduğu Kitab-1 Mukaddes'te net değildir; öte yandan Leviathan ise kaç adet başının olduğunu bilmesek bile, açıkça birden fazla başı olan bir canavardır. Çok başlı olması ve yılana benzer özellikleri dolayısıyla, Leviathan, akla özellikle bir ejderhayı getirmektedir. Leviathan, Behemot ve Rahav adıyla adlı anılan bu üç canavarın da Tanrı tarafından yaratılmış olduklarını tespit edebiliyoruz. Rahav Tanrı tarafindan parçalanmıştır; fakat Leviathan ve Behemot ise günü gelince Tanrı tarafından kılıçla öldürülecek olmalarından dolayı, hayattadırlar. Kitab-1 Mukaddes ekseninde bakıldığında Rahav ölüdür; hayatta olanlar ise Leviathan ve Behemot'tur. Fakat anılan bu iki canavar da ölümsüz değildirler. Lakin sözü edilen bu canavarlar o kadar güçlüdürler ki, sadece Tanrı tarafından öldürülebilirler. $\mathrm{Bu}$ noktada Tanrı, Kitab-1 Mukaddes'te sözü edilen anlatımıyla, kendisinin

\footnotetext{
${ }^{16}$ Burada Rahav, Mısır anlamında kullanılıyor. Kelime olarak Rahav, "firtına" ya da "küstah" anlamına gelir (Kitab-1 Mukaddes, 2011: 742).
} 
dışındakilerin, ne kadar güçlü olurlarsa olsunlar, en güçlünün kendisi olduğunu vurgulamak istemektedir; Tanrı olarak kendisinin gücünün yetmeyeceği bir durumun söz konusu olmadığının ve olamayacağının altını çizmektedir.

\subsection{Thomas Hobbes'un Canavarları: Leviathan ve Behemot}

Genel kamu hukuku disiplini bağlamında ${ }^{17}$ çok önemli bir düşünür olan Thomas Hobbes, "kelimenin tam manasiyla" modern (yani laik) devleti, 1651 tarihli olan Leviathan adlı eseriyle ilk kez dillendiren filozoftur. Hobbes'un öncesinde modernitenin kurucusu olarak anılan isim "egemenlik" kavramının mucidi olan Jean Bodin olmuştur; fakat Bodin'in, modern devlet kavramına iki sorunlu yaklaşımı yüzünden (siyasette Tanrı ile olan bağı tamamen kesemeyişi ve devleti ortaçağa ait bir kavram olan respublica ile ifade etmesi dolayısıyla) "yeterince" modern olamadığını görüyoruz. İşte, Bodin'in eksikliğini gideren, kelimenin tam manasıyla modern olan yani yeterince modern olan (siyasette Tanrı ile olan bağı tamamen kesen ve devleti ifade etmek için respublica kavramına atıf yapmayan) ünlü İngiliz düşünür Hobbes'tur. Pek çok eseri olan Hobbes'un, Kitab-1 Mukaddes'te (Eski Ahit bölümünde) adı geçen canavar yaratıklardan ikisi olan Leviathan ve Behemot'u eserlerine başlık olarak seçtiğini biliyoruz. Sözü edilen bu eserlerden ilki Leviathan"; ikincisi ise "Behemot" olarak karşımızda durmaktadır.

İngiliz iç savaşının sona ermesi ve kral I. Charles'in idam edilmesinden iki yıl sonra, 1651 'de, hem İngiltere'de hem de Fransa' da yayınlanmış olan (Ağaoğulları ve Köker, 2000: 159) Leviathan ${ }^{18}$; İngiliz dilinde yazılmış en önemli felsefi eserdir (Tuck, 2015: 9) ve de Hobbes'a “Malmesburry Canavarı” namını kazandırmıştır (Tuck, 2015: 57).

Leviathan'ın yayınlandığı dönemde İngiltere'de Cromwell iktidarda olduğu için, eser, o evrede yazarının beklediği etkiyi yaratmamıştır. İngiliz dilindeki en yetkin siyaset felsefesi kitabı olarak anılan Leviathan, yayınlandığı dönemde ne parlamento yanlılarını, ne de kralcıları memnun etmiştir (Akın, 1987: 104; Şenel, 1996: 319; Ağaoğulları, 2011: 429; Ağaoğulları ve Köker, 2000: 159). Çünkü Hobbes, kitabında, kraliyetçilerin savunduğu "kralın tanrısal hakları" savını terk eder ve siyasal iktidarın kaynağını, insanların kendi rızaları ile yaptıkları bir sözleșmeye dayandırır. Böylece Hobbes, tanrısal hak düşüncesi yerine "insan yapımı olan sözleşme" düşüncesini geçirmiştir. İkinci olarak Hobbes, sınırsız ve üstün yetkilerle donatılmış mutlak iktidar yanlısı düşünceyi savunduğu için, kralın iktidarını sınırlamak isteyen parlamentocuların tepkisini çekmiștir. Nihayet üçüncü olarak da, Leviathan adlı kitap, dinin bile krala bağımlı olduğu, Kitab-1 Mukaddes'i sadece kralın yorumlayabileceği noktasında içerdiği dinsel görüşler nedeniyle, Fransız Katolik Kilisesinin ve hükümetinin eleştirilerini de üzerine çekmekte gecikmemiştir.

\footnotetext{
${ }^{17}$ Genel kamu hukuku disiplini bağlamında "modern devlet", Jean Bodin ve Thomas Hobbes konusunda ayrıntılı bilgi için bkz., Ağaoğulları ve Köker, 1997: 135-137 ve 190; Ağaoğulları - Köker, 2000: 25-34; Akal, 1998: 15-16, 38, 40, 70-71, 316, 319-323 ve 326; Akın, 1987: 77 ve 95; Couture, 1999: 837; Gönenç, 2007: 148; Haster, 1999: 824; Kapani, 1995: 56-61; Morris, 2001: 831; Şenel, 1996: 284-285; Zabunoğlu, 1963: 20; Zabunoğlu, 1973: 42 ve 113.

18 "Leviathan Bir Din ve Dünya Devletinin İçeriği, Biçimi ve İktidarı" (Leviathan or the Matter, Forme and Power of a Commonwealth Ecclesiastical and Civil) adlı eser, 1651 tarihinde yayınlanmıştır.
} 
Öte yandan Leviathan adlı eser, Hobbes'un görüş değiştirdiği ya da başka bir söyleyişle eski düşüncelerini değiştirip yenilerini ifade ettiği eserdir (Martinich, 2013: 266). "Yurttaşlık Üzerine" adlı kitabında ${ }^{19}$ "Kilisenin, düzen ve disiplin konularında seküler iktidara tabi olduğunu, sadece öğreti konusunda bağımsız olduğunun kabul edilebileceğini" vurgulayan Hobbes; Leviathan adlı eserinde ise fikrini değiştirir ve "kral, dini de kapsar" noktasına (Martinich, 2013: 246) ulaşır. "Hukukun Doğal ve Siyasal Öğeleri” adlı eserinde ${ }^{20}$, "akıldan başka doğal yasa olmaz, Tanrı yoksa bile doğal yasa vardır" görüşünü savunan Hobbes; Leviathan'da ise "doğal yasaların Tanrı kaynaklı olduğunu" vurgular. Hobbes, temelinde bir siyaset felsefesi eseri olan başyapıtı mahiyetindeki kitabına "Leviathan" ismini uygun görmüştür. Bu noktada karşımıza çıkan önemli soru ise Hobbes'un kitabına niçin Leviathan başlığını koyduğudur.

İbranice bir sözcük olan Leviathan'1n temeli (Tunçay, 2005: 205; Ağaoğulları, 2011: 429; Ağaoğulları ve Köker, 2000: 158) ilkin Babil mitolojisine (Babil Yaratılış Destan1) sonra da ikincil olarak Kitab-1 Mukaddes'e uzanır ve Hobbes bu sözcügü Kitab-1 Mukaddes'in Eski Ahit bölümünden ödünç alarak kullanmaktadır. Hobbes, eserinde, Leviathan sözcügünü, "egemen devletin simgesi" olarak kullanmaktadır. Hobbes'a göre devlet çok güçlüdür, hatta toplumun içinde en üstün olandır. Bir ejderhanın (canavarın) gücünün boyutu ne ise, devlet de Hobbes'a göre o derecede bir iktidarın sahibidir ve devlet toplumda kimse tarafindan yıkılamaz. Bu noktada Hobbes, bu yazıda incelenen mitolojik canavarın rolünü devlete vermiştir. Çünkü mitolojide ejderha (canavar), sadece tanrı ya da kahraman tarafindan öldürülebilmektedir. Ejderha (Leviathan), Kitab-1 Mukaddes'te ise sadece Tanrı tarafından öldürülebilir. Fakat devlet de nihayetinde insanlar tarafından kurulmuştur ve sadece Tanrısal kaynaklı bir güç ile ortadan kaldırılabilecektir. Leviathan, Eski Ahitteki ifadesiyle, "bir görünüşüyle insanları yıkan ve gurur oğulları üzerinde kral

\footnotetext{
19 Thomas Hobbes'un De Cive (Yurttaşlık Üzerine) adlı eseri, 1642 yılında yayınlanmıştır. Sözü edilen eserinde Hobbes, kralların yarı ilahi özellikleri olduğunu vurguluyor ve aslında kral, Tanrıdır diyor. Doğal dinin bir vaka olduğunu belirten Hobbes, evreni yaratanın ya da bizi yaratanın büyük bir güce sahip olduğunu, yaratana tapınmanın ise psikolojik bir ihtiyaç olduğunu da eklemektedir. Ateizm günahtır ve doğru tapınma biçimini de ancak Devlet belirler görüşünü savunan Hobbes, kilisenin düzen ve disiplin konularında seküler iktidara tabi olduğunu, sadece öğreti konusunda bağımsız olduğunun kabul edilebileceğinin altını çizmektedir. Martinich, 2013: XIV, 203, 205, 246 ve 262; Zarakolu, 2013: 10 ve 73; Tuck, 2015: 31, 54 ve 132-133.

${ }^{20}$ Thomas Hobbes'un "Hukukun Doğal ve Siyasal Öğeleri” (Elements of Law, Natural and Politic) adlı eseri, 1640 yılında yayınlanmıştır. Ağır bir şekilde emir veren yöneticinin aslında bir tiran olduğunu; ve tiranın katlinin de vacip olduğunu vurgulayan Hobbes, anılan eserinde, kral lehine bir tavır takınmıştır. Hobbes, "Hukukun Doğal ve Siyasal Öğeleri" ve "Yurttaşlık Üzerine" adlı kitaplarında, Kitab-1 Mukaddes'in yorumlanması yetkisini, egemene/devlete değil; kiliseye bırakmıștır. Bir başka söyleyișle Hobbes'un 1642 yılı öncesi düşüncesi, iktidar alanından kilisenin tamamen dışlanması şeklinde değildir ve dostları ise sofulardır. Fakat 1651 tarihli olan Leviathan kitabı ile tüm bu düşüncelerini değiştirmiş olan Hobbes, kilisenin hiçbir özel tarafının olmadığını, Kitab-1 Mukaddes'in sivil bir egemen (yani aslında Devlet) tarafindan yorumlanabileceğini düşünmüş ve ifade etmiş̧tir. Hobbes, kişilerin ise, egemenin/devletin dayattığı inançlar arasından istediğini seçme özgürlügünün olduğunu da vurgulamaktadır. Akıldan başka doğal yasanın olmadığını savunan Hobbes, Tanrı yoksa bile, doğal yasanın var olduğunu düşünmektedir. Hobbes, Leviathan adlı eserinde ne kralcıları, ne de parlamentocuları memnun ettiği için korkup Fransa'ya kaçmıștır. Bu kitabında Hobbes, ticaret özgürlüğünden ve dolaşım özgürlüğünden bahsediyor olmasına rağmen, öteki eserlerinde sözü edilen konulara değinmemiştir. Zarakolu, 2013: 72 ve 215; Martinich,2013: XIV, 60, 139, 184 ve 266; Tuck, 2015: 51-52, 141-143 ve 148.
} 
olan büyük bir su canavarını" anlatmaktadır. Kitab-1 Mukaddes'te, bir dipnot ile Leviathan terimi, "timsah" olarak açıklanmıştır. Fakat başka bazı dillerdeki çevirilerde Leviathan sözcügü bazen timsah, bazen balina, bazen de canavar (ejderha) olarak yorumlanmıştır. Dolayısıyla, Kitab-1 Mukaddes'teki şekliyle Leviathan kullanımının açıkça ne tür bir canlı olduğu net değildir. Fakat Kitab-1 Mukaddes'teki tasvirini dikkate alırsak Leviathan'ın yılana benzeyen, birden fazla başı olan ve ağzından ateş çıkan nitelikleriyle, ağırlıklı olarak mitolojik ejderhayı anımsattığını tekrar vurgulayalım.

Hobbes, mutlak monarşiyi savunduğu ve devlet teorisine ilişkin olarak yazdığı bir eserine başl1k olarak Leviathan'ı koyarken de, devletin gücüne vurgu yapmak istemiş olmalıdır. Devlet de, o kadar güçlüdür ki, sadece tanrı tarafından yok edilebilir; hatta devlet, bir yönüyle yeryüzündeki tanrıdır, çünkü onu yeryüzü canlıları arasında ortadan kaldırabilecek kadar güçlü olan birisi yoktur. Bu bağlamda belki de en önemli nokta, Leviathan'ın niteliklerinden birisidir. Leviathan bir deniz canavarıdır, güçlüdür, en güçlüdür; fakat "tek”tir. Bir başka Leviathan daha yoktur. Sadece tanrı Leviathan'dan üstündür. Tanrı dışında hiç kimse Leviathan'a emir ve talimat veremez. Hobbes, Leviathan'ın “tek” olma özelliğini, devletin yöneticisinin tek kişi olması yani monark (kral) olması noktasında kullanmaktadır. Hobbes'a göre devletin yöneteni de tek kişi olmalıdır ve en üstün olmalıdır; aynen Kitab-1 Mukaddes'te nitelikleri belirtilmiş olan en güçlü yaratık Leviathan gibi. Leviathan "tek"tir; egemen de yani siyasal toplumun yöneteni de "bir"dir. Devlet yönetiminde ikilik, yani iki başl1lık (o dönemde İngiltere'de olduğu gibi iktidarın hem kral, hem de kilise tarafından paylaşılması örneğinde görüldüğü gibi) olmaz, olamaz; aksi halde kaos olur ve toplum yönetilemez. İktidar tek elde fakat kralda toplanmalıdır; kilise de krala tabi olmalı, Kitab-1 Mukaddes'in yorumunu da kral yapmalı yani kilise monarka tabi olmalıdır. Anılan durum, kelimenin tam manasıyla siyasal iktidarın "tek" olması özelliğini yani modern devleti vurgulayan yegane bakış açısıdır ve Hobbes bunu, "tek" güçlü olan Leviathan metaforu bağlamında modern devleti açıklamak için kullanmaktadır.

Döneminin koşulları düşünüldüğünde Hobbes, okuyucularına ve dolayısıyla da topluma (İngiltere' deki) kaosun önlenebilmesi için mutlak monarşik bir devletin zorunlu olduğu fikriyatını, "ezbere" bilmiş olduğu ve uzun yıllar eğitimini gördüğü Kitab-1 Mukaddes eksenindeki örnekten hareketle açıklamış olmalıdır. Hobbes'un, topluma izah etmeye çalıştığı konuyu hem kendisinin anlatabilmesi, hem de toplumun layıkıyla anlayabilmesi için devletin nasıl bir mekanizma olduğunun tasviri bağlamında (en çok çalışılan yerden ya da en iyi bilinen bir kaynaktan ve en önemlisi de) meşruiyeti yüksek bir kaynaktan örnek vermesi, pedagojik açıdan oldukça öğretici olmuş olmalıdır. Zaten Hobbes'un amacı da budur; çünkü toplumu ikna edebilmenin en kolay yolu, toplum ile aynı dili konuşmaktan geçer.

Leviathan'in yılan, timsah, balina, ejderha, canavar ya da bir su canavarı olabileceğine dair yorumlar varsa da, kelimenin tam manasıyla ne tür bir yaratık olduğu bilinmemektedir. Öte yandan şunu biliyoruz: Leviathan, bir yandan Babil miti olan Babil Yaratılış Destanı'nda (Enuma Eliş), bir yandan da Kitab-1 Mukaddes'te geçer; fakat öte yandan, bir de mitolojide her dönem anılan bir "canavar yaratık" 
türüdür. Başka bir söyleyişle, mitolojide "canavar" olarak anlatılan ve anılan "yaratık", Babil mitinde ve Kitab-1 Mukaddes'te kendine özgü isim takılarak Leviathan olarak karşımıza çıkar. Mitolojide Leviathan; ejderha, yılan, timsah ve benzeri bir "canavar yaratık" olarak zikredilmektedir.

Thomas Hobbes'un, yine bir canavar yaratık türünün adı olan "Behemot" (Behemoth or the Long Parliament) adlı eseri (Martinich, 2013: 57-58, 373; Tuck, 2015: 68; Ağaoğulları, 2011: 429-430; Ağaoğulları ve Köker, 2000: 155, 159; Arnhart, 2008: 267; Tunçay, 2005: 205) ise 1679 tarihinde yayınlanmıştır. İngiliz İç Savaşının tarihini ve nedenlerini anlatan bir kitap olan Behemot ve bu bağlamda kullanılan Behemoth sözcüğü, kralcılara karşı savaşan Uzun Parlamentonun sembolü olmak üzere kullanılmıştır. Hobbes, Behemoth adlı eserinde İngiliz İç Savaşının, parlamento ile II. Charles arasında bölünmüş olan ordu yüzünden ortaya çıktığını iddia etmektedir. Dolayısıyla, anılan bu eserinde Hobbes, Behemot ifadesini kaos, karışıklık ve savaş anlamında kullanmaktadır. Bir düzen adamı olan Hobbes, kamu düzeninin bir an önce sağlanmasından yanadır. Kamu düzeninin sağlanmasının yolu ise Hobbes'a göre Behemot'un yani canavarın yok edilmesinden geçmektedir. Çünkü Behemot, yani canavar, aslında bir dehşet öyküsüdür; kaosun timsalidir. Düzenin sağlanabilmesi için Behemot ortadan kaldırılmalıdır ve devletin gücü yeniden en güçlü şekilde tesis edilmelidir. Nihai tahlilde Hobbes, bir "devlet" düşünürüdür; düzenin sağlayıcısı olarak devlet Hobbes için en öncelikli sorundur. Bu yüzden Hobbes, eserine, "yok edilmesi gereken huzursuzluk" anlamına gelen, "öldürülerek ortadan kaldırılması gereken” Behemot başlığını seçmiştir.

İbranice bir sözcük olan ve temeli Babil mitolojisine uzanan Behemot, Kitab-1 Mukaddes'in Eski Ahit bölümünde zikredilmiş olan ve bataklıkta yaşayan (yani sudan uzak duramayan, su ile bağlantılı olan) bir "kara" canavarıdır ve de Hobbes bu sözcügü de yine Eski Ahitten ödünç alarak kullanmaktadır. Behemot sözcüğünün bir su canavarı olarak kullanıldığını, Kitab-1 Mukaddes'in Türkçe çevirisindeki bir dipnotta ise "su aygırı" olarak yorumlandığını belirten kaynakların olduğunu da vurgulayalım. Nihai tahlilde baktığımızda, Hobbes'un iki önemli eserinin (Leviathan ve Behemot), Babil mitolojisinde ve Kitab-1 Mukaddes'te geçen iki canavar yaratıktan esinlenilerek belirlenmiş olduğunu tespit edebiliyoruz. Fakat Kitab-1 Mukaddes'teki üçüncü canavar yaratık olan Rahav ise Hobbes'un eserlerinden birisinin başlığı olamamıştır. Belki de Hobbes daha uzun yaşasaydı, sıradaki eserinin başlı̆̆ Rahav olacaktı; ya da Hobbes, Kitab-1 Mukaddes'teki anlatıya göre "Rahav Tanrı tarafindan öldürülmüş olduğu için", böyle bir "ölü başlığı" tercih etmemiş de olabilir.

\section{Değerlendirme ve Sonuç}

Sözlük anlamıyla mit; öykü, efsane, hikaye ve anlatı gibi ifadeler ile karşılanmaktadır. Mitoloji de bu bağlamda öykülerin incelendiği bir bilim dalı olarak açığa çıkmaktadır. Mitoloji başlığını taşıyan bir kitap, öykülerden ya da diyebiliriz ki efsanelerden bahsediyor demektir. Her toplumun, her kültürün kendi değerlerini yansıtan efsaneleri vardır. Her toplum, efsanelerini kendi özgün değerleri ekseninde kendi işine geldiği gibi, kendine uyarlayarak ve kendi kamu yararını önde tutarak kurgular. Diğer toplumların veya farklı kültürlerin efsanelerinden esinlenilse bile, 
nihayetinde her toplum kendi mitini (efsanesini, öyküsünü) üretir. Aslında mitler, sadece basit birer anlatı olarak değerlendirilmemelidirler; çünkü özellikle Batı'da, varlıklı kişiler kendi efsanelerini çocuklarına okullarda ders konusu olarak okutmuşlardır/öğretmişlerdir. Mitlerde genellikle tanrılar dünyası, kahramanlık hikayeleri ve doğa üstü olaylar anlatılır.

Bugünkü bilgilerimiz ekseninde baktığımızda, ilk uygarlıklardan itibaren mitlerin üretildiği de artık kesinleşmiş gibidir. Çünkü tarihin bilinen ilk uygarlığı olarak kabul edilen Sümerlerden ve Sümerlerin kurguladığı mitlerden haberdarız. Sümerlerden sonra, yine önemli bir uygarlık kurmuş olan Babillerin ürettiği mitlerin de günümüz lisanına çevrim yazıları yapılmıştır. Peki, insanoğlu niçin mit üretmiştir? Aslında yanıt basittir: Sinemanın, televizyonun, gazetelerin, internetin olmadığı bir ortamda insanların doğal ihtiyaçlarının karşılanması gereği mitleri doğurmuştur. Bir başka söyleyișle mitler (efsaneler ya da öyküler), yani anlatılar, gün karardığında ateșin başında oturan insanların sosyalleşmesi için zorunluydular. O halde ünlü mitolog Jean Bottero’yu izleyerek şöyle de ifade edebiliriz: “Öyküler zorunludur; çünkü insanoğlu doğuştan öykücüdür."

Mitlerde yaygınlıkla karşılaşılan bir tema ise "canavar ve bu canavarın bir kahraman (ya da tanrı) tarafından öldürülmesi" anlatısıdır. Hemen her toplumun mitlerinde canavar ve bu canavarın bir kahraman tarafindan öldürülmesi kurgusu bulunmaktadır. Örneklendirirsek; Sümerlerde, Babillerde, Çin ve Hint mitlerinde, Eski Yunan mitlerinde bir süper kahraman ve onun yok ettiği bir canavar öyküsü yaygınlıkla anlatılmıştır.

Mitolojideki akıbeti pek de hayırlı sonuçlanmayan anılan canavar; kimi zaman tüylü yılan, ejderha, öküz başlı tanrı, kimi zaman da kanatlı boğa, insan başlı at veya su canavarı şeklinde tasvir edilmiştir. Artık, öykülerde sözü edilen bu canavar tasviri, mit üreticisinin hayal dünyasının kurgu yeteneğine kalmış bir özelliktir. Sümerlerde, Babillerde, Babillerin bir kabilesi olan Levililerde ve İsrailoğullarının inanç dünyasını yansitan Kitab-1 Mukaddes'te bile canavar olgusu ve anlatısı bulunmaktadır.

Mitolojide yaygınlıkla kullanılan canavar motifi, aslında, "düzen ile kaos arasındaki" mücadeleyi ya da şöyle de ifade edebiliriz, "iyi ile kötü arasındaki savaşı" anlatmaktadır. Düzeni bozan, kaos çıkaran, toplumun huzurunu kaçıran bir canavar vardır ve bu canavarın öldürülmesi gerekir ki, toplumsal refah yeniden sağlansın. "Kötü"yü temsil eden canavar yok edilmelidir ki, hem bireysel, hem de toplumsal “iyi”lik gerçekleştirilebilsin. $\mathrm{Bu}$ eksende baktığımızda, mitolojik canavarın öldürülmesi, hem içten ve diştan gelen (kaynaklanan) kötülüklerin, kaosun yani tehlikelerin ortadan kaldırılmasına işaret etmekte; hem de içimizdeki kötünün varlığının sonlandırılması anlamına gelmektedir. Ejderha ve yılan, mitolojide şeytanın simgesi olarak düşünülmüş ve anlatılmış; huzura ulaşılabilmesi için şeytanın yani canavarların yok edilmesi hakikatine dikkat çekilmiştir.

Mitolojide yaygınlıkla kullanılan ve en çok korkulan motif "ejderha" gibi görünüyor ise de, aslında "yılan", korkulan canavarların başında gelmekte ve en korkuncu olarak anılmaktadır. Gerçekten de yılan, insanoğlunun tarihin her döneminde ciddi manada çekindiği bir canlı türü olmuştur. Mitolojide yılan, derisini değiştirebilme yani 
yeniden dünyaya gelebilme yeteneği ekseninde bir tanrı olarak kabul edilmiş ve yılana tapılmıştır. Genel kamu hukukunun temel kavramı olan "devleti", yılan imgesiyle izah eden bir düşünür de (örneğin, Thomas Hobbes) yılanın mitolojideki algısından hareketle, "devlet yıkılsa bile yeniden doğar" ya da "devlet süreklidir, yılan gibidir, hiç ölmez" perspektifinden konuya bakmış olmalıdır.

Uygarlığın ilk kurucusu olarak kabul edilen Sümerlerde ve sonrasındaki medeniyet olan Babillerde canavar motifi ve bu canavarın öldürülmesine ilişkin anlatıların olduğuna yukarıda değinilmişti. Bu yazı bağlamında, Sümerlere ait olan ve "canavarın öldürülmesi" motifini içeren "beş" öykü; Babillere ait olan ise "üç" öykü incelenmiştir. Dolayısıyla bu makalede bir canavarın öldürülmesini içeren toplamda "sekiz" mitolojik öykü incelenmiş olmakta; ulaşılan vargılar da bu anılan "sekiz" anlatı ekseninde karşımızda durmaktadır.

Sümerlere ait olan "beş" mitolojik öykü incelendiğinde, öyküde geçen canavarın adının ve fiziksel özelliklerinin dört anlatıda olmadığını görüyoruz. Sadece tek öyküde (tanrı Tişpak ve canavar Labbu) canavarın adı ve fiziksel özellikleri belirtilmiştir. Gılgamış öyküsünde canavar rolü bir "yılana" oynatılırken, iki öyküde (Ninurta ve Tişpak öykülerinde) ise "su canavarı" motifi kullanılmıştır. Anılan her beş Sümer öyküsünde de kaosun kaynağı bir canavardır. Beş öyküden dördünde sorunu çözen bir tanrıdır; bir öyküde ise (Gılgamış) kahraman yarı tanrı-yarı insandır. Dolayısıyla, aslında anılan beş öykünün mesajı "tanrılar güçlüdürler, sorunları çözerler, kamu düzenini sağlarlar, tanrılara güvenilmesi gerekir, toplumsal moralin bozulmasına gerek yoktur" noktasında berraklaşmakta ve öyküler topluma moral aşılamakta ya da toplumun moralini yükseltmek istemektedirler. İşte tam da geldiğimiz noktada, bu makalenin yanıtını aradığı ilk problem olan "Sümerlerde canavar öldürme hangi anlama gelir?" sorusu da yanıtını bulmuş olmaktadır. Sümer mitleri, topluma, "tanrılar kaosu önler, endişe etmeyin, tanrılara güvenin, moralinizi yüksek tutun" noktasında mesaj vermektedir.

Babillere ilişkin olarak incelediğimiz "üç" öyküde de yine canavar ve bu canavarın öldürülmesi olgusu söz konusudur. Öykülerden birisinde canavarın adı (Humbaba) ve bu canavarın fiziksel özellikleri dillendirilmişken; geriye kalan iki öyküde ise canavarın adı ve fiziksel özellikleri tasvir edilmiş değildir. Babillere ilişkin olan bir öyküde canavarlık rolü "yılana" oynatılırken; öteki öyküde canavarlık rolü ise bir tanrıçaya (Tiamat) aktarılmıştır. Her üç öyküde de mevcut olan canavar, esasında kaos sembolüdür; toplumun ihtiyaçlarının giderilmesinin önündeki en büyük engeldir. İki öyküde toplumun "kereste" ihtiyacı vardır; fakat canavar bu ihtiyacın karşılanmasını engellemektedir. Geriye kalan bir öyküde ise canavar, öldürülen kocasının öcünü almayan, şımarık çocukları (aslında genç tanrıları) cezalandırmayan yani sorumluluğunu yerine getirmeyerek toplumsal adalet ihtiyacının karşılanmasını önleyen bir rolün sahibi olarak dillendirilmektedir.

Her üç Babil efsanesinde de canavar öldürülür; yani kaos giderilir ve toplumsal huzur sağlanır. Fakat iki anlatıda sorunu çözen yarı tanrı yarı insan gibi gözüküyor olsa da aslında yönetici-kral (yani insan) olur; tanrılar değil. Bahsi geçen iki öykü, anılan yönüyle yöneticilerin de yani insanların da kendi sorunlarını çözebileceğini işaret etmekte ve tanrıları sorun çözücü olarak gündeme taşımamaktadır. Babillere ait olan 
sadece bir öyküde sorunu tanrı Marduk çözümlemektedir. Öte yandan Humbaba öyküsünde, insanın tanrı soyundan gelen bir canavarı öldürmesi ve tanrıçanın aşkına karşılık verilmemesi üzerine, tanrıların müeyyide uyguladığına ve uygulayacağına da işaret edilmektedir. Tanrı Marduk ve tanrıça Tiamat öyküsü ise iki konu açısından özellik arz etmektedir. İlkin, öyküde kullanılmış olan Leviathan ibaresidir. Leviathan ibaresi, inceleyebildiğimiz kadarıyla ilk kez bir Babil efsanesinde kullanılmıştır ve de bir "deniz canavarını" ifade etmektedir. Kitab-1 Mukaddes'teki Leviathan kullanımı ise anılan bu bilgiyi dikkate aldığımızda, Leviathan ibaresinin kullanıldığı ikinci materyal olmaktadır. Daha basit olarak ifade edersek, Leviathan terimi ilkin bir Babil anlatısında; ikinci kez ise Kitab-1 Mukaddes'te kullanılmıştır.

$\mathrm{Bu}$ makalenin yanıtını aradığı sorulardan ikincisi "canavar ve canavar öldürme motifinin Babillerdeki anlamı" idi. Artık ulaştığımız bu noktada, anılan sorunun yanıtını da verebiliriz. Babil mitolojisindeki canavar ve canavar öldürme motifinin arz ettiği anlam ise "kötülüğün", kaosun ortadan kaldırılması ve toplumsal huzurun sağlanması șeklinde karşımıza çıkmaktadır. Yani Babil mitinde de canavar, Sümerlerde olduğu gibi kaosu temsil eder; fakat Babil anlatılarında sorunları her zaman tanrı değil, insanlar da çözebilmektedir. Sümerler ile karșılaștırıldığında, Babil öykülerinde toplumsal sorunların çözülmesindeki kahraman çoğunlukla insan odaklı olarak kurgulanmıştır. Babil mitleri söz konusu olduğunda kadına verilen önemin, Sümer efsanelerine göre daha düşük olduğunu da söyleyebiliriz. Çünkü Babil mitinde kadın, "sorumluluklarını yerine getirmeyerek toplumsal adaletin teminine engel olan bir rolün" sahibi olarak (örneğin tanrıça Tiamat) yansıtılmaktadır.

Leviathan adıyla adlı canavar ilkin Babil Yaratılış Destanı'nda, sonrasında ise Kitab-1 Mukaddes'te kendisine yer bulmaktadır. Kitab-1 Mukaddes'te Leviathan, çok baş1 olan "yılana" benzetilmiştir, dolayısıyla ejderhadır ve deniz canavarıdır. Tanrı tarafından "tek" olarak yaratılan Leviathan, o kadar güçlüdür ki, sadece Tanrı tarafından öldürülebilir. Bu bağlamda Leviathan terimi, Babil Yaratılıș Destanı'ndan hatırladığımız tanrıça Tiamat'ın doğurduğu leviathanları akla getirmektedir. Tanrıça Tiamat'ın doğurduğu leviathanlar da, tanrı Marduk tarafından etkisiz hale getirilmişlerdi.

Kitab-1 Mukaddes'teki anlatı ekseninde bakıldığında "güç odakları" açısından sanki hiyerarşik bir vurgu var gibi gözüküyor. En güçlü olan Tanrı'dır; ikinci sırada ise Leviathan gelir. Bir başka söyleyişle Kitab-1 Mukaddes'e göre Tanrı'dan sonra en güçlü olan Leviathan'dır. Aslında Kitab-1 Mukaddes'te (Eski Ahit bölümünde) Leviathan dışında Behemot ve Rahav adıyla adlı iki canavar daha zikredilmektedir ve Kitab-1 Mukaddes'te zikredilen üç canavar da esasında "güç" sembolüdürler ve sadece Tanrı tarafından öldürülebilirler. Zaten Rahav öldürülmüștür bile. Kitab-1 Mukaddes'in Eski Ahit bölümünde anılan her üç canavarı da Tanrı yaratmıştır. Yani Tanrı, Kitab-1 Mukaddes'te zikretmiş olduğu bu canavarlar ile kendisinin gücüne atıfla, sonsuz bir iktidarın sahibi olduğunu anlatmak istemektedir. Kim olursa olsun, ne olursa olsun, deniz canavarı, yılan ya da ejderha (Leviathan) olsa bile; bataklıkta yaşayan çok güçlü ve korkunç (Behemot) bir yaratık olsa bile, ya Tanrı tarafından zaten öldürülmüsstür, ya da günü gelince Tanrı tarafından öldürülürler. Dolayısıyla, vardığımız noktada, bu makalenin yanıtını aradığı "Kitab-1 Mukaddes'te Leviathan 
(ya da canavar olgusu) hangi anlama gelir?" sorusu da yanıtını bulmuş olmaktadır. Leviathan ya da öteki canavarlar, Kitab-1 Mukaddes'te Tanrı'nın çok güçlü olduğunu, kadir-i mutlak olduğunu vurgulamak bağlamında "anlaşılması kolay olan örnekler" olarak kullanılmışlardır; yani altı çizilmek istenen mevzu "Tanrı'nın gücü” olmuştur.

Babil Yaratılış Destanı'ndan ve Kitab-1 Mukaddes'ten sonra Leviathan ibaresini üçüncü kez; fakat bu sefer bir kitap başlığı olarak görüyoruz. Thomas Hobbes, "mutlak monarşik devleti” anlattığı eserine "devlet yeryüzündeki en güçlüdür" anlamında Leviathan başlığını vermiştir. Kitab-1 Mukaddes'te en güçlü olan Tanrı; ikinci olarak en güçlü olan ise Leviathan idi. Bu noktada Hobbes, devletin gücünün Tanrı'dan sonra gelen “ikinci en güçlü" olduğunu vurgulamak ve anlatmak istemektedir. İnsanlar nasıl ki Tanrı'nın emirlerine uyarlar; Hobbes'a göre benzer şekilde devletin de buyruklarına uyulmalıdır. Kitab-1 Mukaddes'te Leviathan'ın en önemli özelliklerinden birisi "tek" olmasıydı. Hobbes da mutlak monarşik devlet savunusu mahiyetinde olan baş yapıtına Leviathan adlandırmasını uygun görmüştür; çünkü Hobbes devleti "tek" kişinin yani kralın yönetmesini istemektedir. Tanrı'dan sonra gelen ve "en güçlü ikinci" olan kralın emirleri Tanrı'nın emirleri gibi yerine getirilmelidir. Hatta kral, Hobbes'a göre o kadar güçlüdür ki "yeryüzündeki Tanrı" gibidir. Hobbes, öteki eseri için belirlediği "Behemot" başlığını ise kaos, huzursuzluk, kargaşa anlamında kullanıyor; çünkü Behemot adlı eserinde Hobbes, İngiliz iç savaşını anlatmakta, savaşın sebebi olarak da iktidarın yani gücün parlamento ile kral arasında bölünmüş olmasını göstermektedir. Hobbes'a göre Behemot öldürülmeli, kamu düzeni sağlanmalı ve iktidar "tek" elde toplanmalıdır. Kitab-1 Mukaddes'in Eski Ahit bölümünde adı geçen üçüncü canavar olan Rahav ise Hobbes'un eserlerinden birisinin başlığ 1 olarak tercih edilmiş değildir. Çünkü Kitab-1 Mukaddes'e göre Rahav, zaten Tanrı tarafindan öldürülmüştür. Ünlü İngiliz siyaset filozofu Hobbes, eserlerinden birisine "ölü bir başlık" koymayı tercih etmemiş olmalıdır. Ya da Hobbes, daha uzun yaşasaydı, hayatının son dönemine ait olan sıradaki eserinin başlığı belki de Rahav olacaktı.

$\mathrm{Bu}$ makalenin yanıtını aradığı sorulardan birisi de "Hobbes'ta Leviathan (yani canavar) hangi anlama gelmektedir?" şeklinde idi. Dolayısıyla anılan sorunun yanıtını da geldiğimiz bu noktada artık açıklığa kavuşturabiliriz. Hobbes’ta canavar, öncelikle "güç/iktidar" anlamında (yani "egemenlik" anlamında); sonra da ikincil olarak "kaos, huzursuzluk" (iktidarın ikiye bölünmüş olması) anlamında kullanılmaktadır. Leviathan adlı deniz canavarı "devletin (yani kralın) gücünü"; Behemot adlı bataklık canavarı ise "İngiltere'de iç savaştan kaynaklanan kaosu" (yani iktidarın ikiye bölünmüş olmasını) sembolize etmektedir. Devlet, Hobbes'a göre "Tanrı'dan sonra gelen en güçlü"dür ve "tek"tir; Behemot ise bir kahraman tarafindan öldürülmelidir ki, toplumsal düzen yeniden sağlansın, kamu yararı gerçekleştirilsin, toplum huzura kavuşturulsun ve devlet en güçlü bir şekilde iktidarını tek elde gerçekleştirebilsin. Yani Hobbes'a göre Behemot yok edilmeli; Leviathan ise yaşatılmalıdır. Hobbes'un düşünsel dünyasında Leviathan uğruna Behemot feda edilmelidir. Ya da kral (yani mutlak egemen, bir başka söyleyişle devlet) kamu düzenini sağlamak adına kaos timsali olan Behemot'u zaten yok edecektir; hatta etmelidir de. Değişik bir söyleyişle belirtirsek, iki başlı iktidar yapısına son verilmeli, iktidar (güç) "tek" elde toplanmalıdır. Aslında Hobbes Leviathan ile Behemot'u çatıştırmakta; Behemot'un 
Leviathan tarafından mağlubiyete uğratılmasını istemekte, dolayısıyla da Leviathan'1n tarafinı tutmakta, Leviathan'1 desteklemektedir.

Özüne indirgersek, "canavar ve canavar öldürme" motifi Sümerlerde özellikle ve yaygınlıkla tanrıların gücüne; Babillerde ise özellikle ve yaygınlıkla insanların da (fakat özellikle erkeklerin de) tanrılar gibi güçlü olabileceğine işaret etmektedir. Her toplumun mitinde karşılaşılan "canavar", zaman içerisinde dönem dönem değişik isimler ile (Labbu, Humbaba, Tiamat ya da Huvava vs. gibi) anılmıştır. Değişik adlandırmalar altında anlatılarda kendisine yer bulmuş olan canavarın adı Babillerde ise Leviathan olmuştur. Leviathan ibaresini Kitab-1 Mukaddes de bir canavar adı olarak benimsemiştir. Kaldı ki, Kitab-ı Mukaddes'te (Eski Ahit bölümünde) Leviathan'ın dişında Behemot ve Rahav adlı iki canavardan daha bahsedilmektedir. Nihayetinde Leviathan, Thomas Hobbes'un eserlerinden birisinin başlı̆̆ da olmuştur. Hobbes'un öteki eserinin adı ise Behemot'tur. Kitab-1 Mukaddes'te Leviathan ve öteki canavarlar (behemot ve Rahav) Tanrı'nın en güçlü olduğunu anlatmak amacıyla kullanılmışlardır. Thomas Hobbes da eseri için başlık olarak belirlediği Leviathan'1 “devlet Tanrı'dan sonra gelen en güçlüdür” anlamında; Behemot'u ise kaos ve savaş anlamında kullanmıştır.

Thomas Hobbes, genel kamu hukuku disiplinine ilişkin olan iki eserinin başlığını (Leviathan ve Behemot) Kitab-1 Mukaddes'in Eski Ahit bölümünden almıştır. Sözü edilen durumun ise iki sebebinin olduğu söylenebilir. İlkin, "Hobbes ateist değildir, iyi bir Kitab-1 Mukaddes inananıdır ve perspektifini Kitab-1 Mukaddes'ten almaktadır" argümanı ileri sürülebilecektir. İkinci sebep olarak da, Hobbes'un anlatmak istediği "devlet iktidarının gücü", en çok bilinen bir kaynak olan Kitab-1 Mukaddes örnekleri ile anlatılırsa meşruiyet ve toplumsal algilama daha yüksek olacaktır" düşüncesi gündeme getirilebilecektir. Kitab-1 Mukaddes'te "Tanrı'dan sonra en güçlü olan" yani "ikinci en güçlü olan" Leviathan'dır. Hobbes da devlete (yani egemene ya da krala) Leviathan derken, "Tanrı'dan sonra en güçlü olan"ın devlet olduğunu anlatmak istemektedir. Bu yönüyle Hobbes, Kitab-1 Mukaddes'te benimsenmiş olan "anlatım tekniğini" kendi özgün fikirlerine uyarlamakta ve Tanrı'nın, Kitab-1 Mukaddes'teki yöntemini kullanmakta, devletin gücünün/iktidarının “tek” olması gerekliliğini vurgulamaktadır.

\section{Kaynakça}

Adam, B. (2012), Tevrat, İslam Ansiklopedisi, Cilt: 41, 40-45.

Ağaoğulları, M. A. (2011), Sokrates'ten Jakobenlere Batı'da Siyasal Düşünceler, İletişim Yayınları, İstanbul.

Ağaoğulları, M. A.ve Köker, L. (1997), Tanrı Devletinden Kral Devlete, İmge Kitabevi, Ankara.

Ağaoğulları, M. A.ve Köker, L. (2000), Kral-Devlet ya da Ölümlü Tanrı, İmge Kitabevi, Ankara.

Akal, C. B. (1998), İktidarın Üç Yüzü, Ankara: Dost Kitabevi.

Akın, İ. F. (1987), Kamu Hukuku, İstanbul: Beta Yayınları. 
Arnhart, L. (2008), Siyasi Düşünce Tarihi, Plato'dan Rawls'a, (Çev.: Ahmet Kemal Bayram), Adres Yayınları, Ankara.

Babil Yaratılış Destanı (Enuma Eliş). (2016) Anonim, (Çev.: F. Selim Adalı ve T. Ali Görgü), Türkiye İş Bankası Kültür Yayınları, İstanbul.

Bottero, J, ve Kramer, S. N. (2017), Mezopotamya Mitolojisi, (Çev.: Alp Tümerkan), Türkiye İş Bankası Yayınları, İstanbul.

Burn, L. (2017), Yunan Mitleri, (Çev.: Nagehan Tokdoğan), Phoenix Yayınevi, Ankara.

Büyük Larousse Sözlük ve Ansiklopedisi. (1993), 24 cilt, Milliyet Gazetecilik A.Ş.

Campbell, J. (2015a), İlkel Mitoloji, Tanrı'nın Maskeleri-I, (Çev.: Kudret Emiroğlu), Islık Yayınları, İstanbul.

Campbell, J. (2015b), Batı Mitolojisi Tanrının Maskeleri-II, (Çev.: Kudret Emiroğlu), Islık Yayınları, İstanbul.

Campbell, J. (2015c), Yaratıcı Mitoloji, Tanrının Maskeleri - IV, (Çev.: Kudret Emiroğlu), Islık Yayınları, İstanbul.

Can, Ş. (2015), Klasik Yunan Mitleri, Ötüken Yayınları, İstanbul.

Couture, T. (1999), "State", Christopher Berry Gray (Ed.), Philosophy of Law, Volume 2 içinde, (834-837), Garland Publishing, New York.

Çığ, M. İ. (2017a), Kuran, İncil ve Tevrat'ın Sümer'deki Kökeni, Kaynak Yayınları, İstanbul.

Çı̆̆, M. İ. (2017b), İbrahim Peygamber, İstanbul: Kaynak Yayınları.

Çı̆̆, M. İ. (2017c), Gilgameş, Tarihte İlk Kral Kahraman, Kaynak Yayınları, İstanbul.

Dell, C. (2014), Canavarlar, (Çev.: Nurettin Elhüseyni), Yapı Kredi Yayınları, İstanbul.

Gılgamış Destanı (2016), Anonim, Çeviren: Sait Maden, Türkiye İş Bankası, Kültür Yayınları, İstanbul.

Erdem, S. (1991), Babil, İslam Ansiklopedisi Cilt: 4, 392-395.

Gönenç, L. (2007), "Siyasal İktidar Kavramı Bağlamında Anayasa Çalışmaları İçin Bir Kavramsal Çerçeve Önerisi”, $A \ddot{U} H F D, 56$ (1), 145-168.

Gürkan, S. L. (2010), Şeytan, İslam Ansiklopedisi, Cilt: 39, 99-103.

Gürkan, S. L. (2013), Y1lan, İslam Ansiklopedisi, Cilt: 43, 527-529.

Harman, Ö. F. (1988), Ahd-i Atik, İslam Ansiklopedisi, Cilt: 1, 494-501.

Harman, Ö. F. (2002), Kitab-1 Mukaddes, İslam Ansiklopedisi, Cilt: 26, 75-76.

Haster, T. L. (1999), "Sovereignty", Christopher Berry Gray (Ed.), Philosophy of Law, Volume 2 içinde, (824-826), Garland Publishing, New York. 
Jursa, M. (2017), Babilliler, (Çev.: Firuzan Gürbüz Gerhold), Alfa Yayınları, İstanbul.

Kapani, M. (1995), Politika Bilimine Giriş, Bilgi Yayınevi, Ankara.

Kramer, S. N. (2016), Tarih Sümer'de Başlar, (Çev.: Hamide Koyukan), Kabalcı Yayınc1lı, İstanbul.

Kramer, S. N. (2014), Sümer Mitolojisi, (Çev.: Hamdi Koyukan), Kabalcı Yayıncılık, İstanbul.

Leeming, D. A. (2017), Dünya Mitolojisi, (Çev.: Nurdan Soysal), İstanbul: Say Yayınları.

Martinich, A. P. (2013), Thomas Hobbes, (Çev.: Akın Terzi), Türkiye İş Bankası Yayınları, İstanbul.

Mcneill, W. H. (2003), Dünya Tarihi, (Çev.: Alaeddin Şenel), İmge Kitapevi Yayınları, Ankara.

Morris, C. (2001), "Sovereignty", Paul Barry Clarke and Joe Foweraker (Ed.), Encyclopedia of Democratic Thought, içinde, (829-832), Routledge, London.

Newton, I. (2016), Kutsal Kitabın Yorumu, (Çev.: Emre Alagöz), Panama Yayınları, Ankara.

Roberts, J. M. (2011), Dünya Tarihi Cilt: I, (Çev.: İdem Erman), İnkılap Kitapevi, İstanbul.

Sarıtoprak, Z. (1993), “Dabbetül Arz”, İslam Ansiklopedisi, Cilt: 8, 393-395.

Şahin, M. S. (1993), “Cin”, İslam Ansiklopedisi, Cilt: 8, 5-8.

Şenel, A. (2006), Kemirgenlerden Sürüngenlere İnsanlık Tarihi, İmge Kitapevi Yayınları, Ankara.

Şenel, A. (1996), Siyasal Düşünceler Tarihi, Ankara: Bilim ve Sanat Yayınları.

Tanyu, H. (1988), “Ahd-i Cedid”, İslam Ansiklopedisi, Cilt: 1, 501-507.

Tuck, R. (2015), Hobbes, (Çev.: Nursu Örge), Dost Kitabevi, Ankara.

Tunçay, M. (2005), Batı'da Siyasal Düşünceler Tarihi, İstanbul Bilgi Üniversitesi Yayınları, İstanbul.

Zabunoğlu, Y. K. (1963), Devlet Kudretinin Sınırlanması, Ajans-Türk Matbaası, Ankara.

Zabunoğlu, Y. K. (1973), Kamu Hukukuna Giriş, Ankara: AÜHF Yayınları.

Zarakolu, C. D. (2013), Thomas Hobbes'un Siyaset Felsefesi, Belge Yayınları, İstanbul. 